\title{
Glacier algae accelerate melt rates on the south-western Greenland Ice Sheet
}

\author{
Joseph M. Cook ${ }^{1,2}$, Andrew J. Tedstone ${ }^{3}$, Christopher Williamson ${ }^{4}$, Jenine McCutcheon ${ }^{5}$, Andrew J. Hodson ${ }^{6,7}$, \\ Archana Dayal $^{1,6}$, McKenzie Skiles ${ }^{8}$, Stefan Hofer ${ }^{3}$, Robert Bryant ${ }^{1}$, Owen McAree ${ }^{9}$, Andrew McGonigle ${ }^{1,10}$, \\ Jonathan Ryan $^{12}$, Alexandre M. Anesio ${ }^{13}$, Tristram D. L. Irvine-Fynn ${ }^{11}$, Alun Hubbard ${ }^{14}$, Edward Hanna ${ }^{15}$, \\ Mark Flanner $^{16}$, Sathish Mayanna ${ }^{17}$, Liane G. Benning ${ }^{5,17,18}$, Dirk van As ${ }^{19}$, Marian Yallop ${ }^{4}$, James B. McQuaid ${ }^{5}$, \\ Thomas Gribbin ${ }^{3}$, and Martyn Tranter ${ }^{3}$ \\ ${ }^{1}$ Department of Geography, University of Sheffield, Winter Street, Sheffield, South Yorkshire, S10 2TN, UK \\ ${ }^{2}$ Institute of Biological, Environmental and Rural Sciences, Aberystwyth University, Aberystwyth, SY23 3DA, UK \\ ${ }^{3}$ Bristol Glaciology Centre, School of Geographical Sciences, University of Bristol, Berkely Square, Bristol, BS8 1RL, UK \\ ${ }^{4}$ School of Biological Sciences, University of Bristol, Tyndall Ave, Bristol, BS8 1TQ, UK \\ ${ }^{5}$ School of Earth and Environment, University of Leeds, Leeds, LS2 9JT, UK \\ ${ }^{6}$ Department of Geology, University Centre in Svalbard, Longyearbyen, 9171, Norway \\ ${ }^{7}$ Department of Environmental Sciences, Western Norway University of Applied Sciences, 6856 Sogndal, Norway \\ ${ }^{8}$ Department of Geography, University of Utah, Central Campus Dr, Salt Lake City, Utah, USA \\ ${ }^{9}$ Faculty of Science, Liverpool John Moores University, James Parsons Building, Byrom Street, Liverpool, L3 3AF, UK \\ ${ }^{10}$ School of Geosciences, University of Sydney, Sydney, NSW 2006, Australia \\ ${ }^{11}$ Department of Geography and Earth Science, Aberystwyth University, Wales, SY23 3DB, UK \\ ${ }^{12}$ Institute at Brown for Environment and Society, Brown University, Providence, Rhode Island, USA \\ ${ }^{13}$ Department of Environmental Science, Aarhus University, 4000 Roskilde, Denmark \\ ${ }^{14}$ Centre for Gas Hydrate, Environment and Climate, University of Troms $\varnothing, 9010$ Troms $\varnothing$, Norway \\ ${ }^{15}$ School of Geography and Lincoln Centre for Water and Planetary Health, University of Lincoln, Think Tank, Ruston Way, \\ Lincoln, LN6 7DW, UK \\ ${ }^{16}$ Climate and Space Sciences and Engineering, University of Michigan, 2455 Hayward St. Ann Arbor, Michigan, USA \\ ${ }^{17}$ German Research Centre for Geosciences, GFZ, Potsdam, Germany \\ ${ }^{18}$ Department of Earth Sciences, University of Berlin, Berlin, Germany \\ ${ }^{19}$ Geological Survey of Denmark and Greenland, Copenhagen, Denmark
}

Correspondence: Joseph M. Cook (joc102@aber.ac.uk)

Received: 18 March 2019 - Discussion started: 3 April 2019

Revised: 16 December 2019 - Accepted: 18 December 2019 - Published: 29 January 2020

\begin{abstract}
Melting of the Greenland Ice Sheet (GrIS) is the largest single contributor to eustatic sea level and is amplified by the growth of pigmented algae on the ice surface, which increases solar radiation absorption. This biological albedo-reducing effect and its impact upon sea level rise has not previously been quantified. Here, we combine field spectroscopy with a radiative-transfer model, supervised classification of unmanned aerial vehicle (UAV) and satellite remote-sensing data, and runoff modelling to calculate biologically driven ice surface ablation. We demonstrate that al-
\end{abstract}

gal growth led to an additional 4.4-6.0 Gt of runoff from bare ice in the south-western sector of the GrIS in summer 2017, representing $10 \%-13 \%$ of the total. In localized patches with high biomass accumulation, algae accelerated melting by up to $26.15 \pm 3.77 \%$ (standard error, SE). The year 2017 was a high-albedo year, so we also extended our analysis to the particularly low-albedo 2016 melt season. The runoff from the south-western bare-ice zone attributed to algae was much higher in 2016 at $8.8-12.2 \mathrm{Gt}$, although the proportion of the total runoff contributed by algae was similar at 
$9 \%-13 \%$. Across a $10000 \mathrm{~km}^{2}$ area around our field site, algae covered similar proportions of the exposed bare ice zone in both years (57.99\% in 2016 and $58.89 \%$ in 2017), but more of the algal ice was classed as "high biomass" in 2016 $(8.35 \%)$ than $2017(2.54 \%)$. This interannual comparison demonstrates a positive feedback where more widespread, higher-biomass algal blooms are expected to form in highmelt years where the winter snowpack retreats further and earlier, providing a larger area for bloom development and also enhancing the provision of nutrients and liquid water liberated from melting ice. Our analysis confirms the importance of this biological albedo feedback and that its omission from predictive models leads to the systematic underestimation of Greenland's future sea level contribution, especially because both the bare-ice zones available for algal colonization and the length of the biological growth season are set to expand in the future.

\section{Introduction}

Mass loss from the Greenland Ice Sheet (GrIS) has increased over the past 2 decades (Shepherd et al., 2012; Hanna et al., 2013) and is the largest single contributor to cryospheric sea level rise, adding $37 \%$ or $0.69 \mathrm{~mm} \mathrm{yr}^{-1}$ between 2012 and 2016 (Bamber et al., 2018). This is due to enhanced surface melting (Ngheim et al., 2012) that exceeds calving losses at the ice sheet's marine-terminating margins (Enderlin et al., 2014; van den Broeke et al., 2016). Surface melting is controlled by net solar radiation, which in turn depends upon the albedo of the ice surface, making albedo a critical factor for modulating ice sheet mass loss (Box et al., 2012; Ryan et al., 2018a). The largest shift in albedo occurs when the winter snow retreats to expose bare glacier ice. However, there are several linked mechanisms that then change the albedo of the exposed ice and determine its rate of melting, including meltwater accumulation, ice surface weathering and the accumulation of light-absorbing particles (LAPs), such as soot (Flanner et al., 2007) and mineral dust (Skiles et al., 2017). Photosynthetic algae also reduce the albedo of the GrIS (Uetake et al., 2010; Yallop et al., 2012; Stibal et al., 2017; Ryan et al., 2017, 2018b). Despite being identified in the late 1800s (Nordenskiöld, 1875), their effects have not yet been quantified, mapped or incorporated into any predictive surface mass balance models (Langen et al., 2017; Noël et al., 2016; Fettweis et al., 2017). Hence, biological growth may play an important yet underappreciated role in the melting of the Greenland Ice Sheet and its contributions to sea level rise (Benning et al., 2014).

The snow-free surface of the GrIS has a conspicuous dark stripe along its western margin that expands and contracts seasonally, covering $4 \%-10 \%$ of the ablating bare-ice area (Shimada et al., 2016). The extent and darkness of this "dark zone" may be biologically and/or geologically controlled
(Wientjes et al., 2011, 2016; Tedstone et al., 2017; Stibal et al., 2017). There is a growing literature demonstrating the albedo-reducing role played by a community of algae that grow on glacier ice on the eastern (Lutz et al., 2014) and western (Uetake et al., 2010; Yallop et al., 2012; Stibal et al., 2017; Tedstone et al., 2017; Williamson et al., 2018) GrIS. The algal community on the GrIS is dominated by Mesotaenium berggrenii and Ancylonema nordenskioldii (Yallop et al., 2012; Stibal et al., 2017; Williamson et al., 2018, 2019; Lutz et al., 2018), which are collectively known as "glacier algae" to distinguish them from snow algae and sea ice algae. The presence of these glacier algae reduces the albedo of the ice surface, mostly due to a purple purpurogallin-like pigment (Williamson et al., 2018; Stibal et al., 2017; Remias et al., 2012).

An equivalent albedo reduction due to algae has also been studied on snow. Worldwide, snow algal communities are dominated by unicellular Chlamydomonaceae, the most abundant of which belong to the collective taxon Chlamydomonas nivalis (Leya et al., 2004). These algae have been shown to be associated with low-albedo snow in eastern Greenland (Lutz et al., 2014) and to be responsible for $17 \%$ of snowmelt in Alaska (Ganey et al., 2017). However, for glacier algae, quantification of the biological albedo reduction, radiative forcing and melt acceleration has remained elusive due to the difficulty of separating biological from non-biological albedo-reducing processes and a lack of diagnostic biosignatures for remote sensing. For snow, remote detection has been achieved by measuring the "uniquely biological" chlorophyll absorption feature at $680 \mathrm{~nm}$ (Painter et al., 2001), a broader carotenoid absorption feature (Takeuchi et al., 2006), a normalized difference spectral index (Ganey et al., 2017) and a spectral unmixing model (Huovinen et al., 2018). However, these signature spectra can be ambiguous for glacier algae due to the presence of the phenolic pigment with a broad range of absorption across the UV and VIS wavelengths that obscures features associated with other pigments in raw reflectance spectra and is further complicated by the highly variable optics of the underlying ice and mixing of algae with other impurities.

The dark zone is of the order $10^{5} \mathrm{~km}^{2}$ in extent and is undergoing long-term expansion (Shimada et al., 2016; Tedstone et al., 2017). Quantifying the impact of algal colonization on the dark zone is therefore paramount. Upscaling of unmanned aerial vehicle (UAV) observations made in a small sector of the dark zone to satellite data has demonstrated that "distributed impurities" including algae exert a primary control on the surface albedo, but isolating the biological effect and upscaling to the regional scale has been prevented by a lack of spectral resolution and ground validation (Ryan et al., 2018a). Recently, Wang et al. (2018) applied the vegetation red edge (difference in reflectance between 673 and $709 \mathrm{~nm}$ ) to map glacier algae over the south-western GrIS using Sentinel-3 OLCI data at $300 \mathrm{~m}$ ground resolution. Nei- 
ther of these previous studies quantified the effect of glacier algae effect on albedo or melt at the regional scale.

Here, we directly address these issues, resolving a major knowledge gap limiting our ability to forecast ice sheet melt rates into the future. First, we use spectroscopy to quantify the effect of glacier algae on albedo and radiative forcing in ice. We then use a new radiative-transfer model to isolate the effects of individual light-absorbing particles on the ice surface for the first time, enabling a comparison between local mineral dust and algae and providing the first candidate albedo parameterization that could enable glacier algae to be incorporated into mass balance models. To determine spatial coverage, we apply a supervised classification algorithm (random forest) to map glacier algae in multispectral UAV and satellite data. Runoff modelling informed by our empirical measurements and remote-sensing observations enables us to estimate the biological contribution to GrIS runoff for the first time.

\section{Field sites and methods}

\subsection{Overview}

In this study we present a suite of empirical, theoretical and remote-sensing data to quantify and map algal contributions to melting on the south-western GrIS. At our field site we paired spectral reflectance and albedo measurements with removal of surface ice samples for biological and mineralogical analyses in order to quantify the relationship between cell abundance and broadband and spectral albedo. The imaginary part of the refractive index of the local mineral dusts and the purpurogallin-type phenolic compound that dominates absorption in the local glacier algae were measured in the laboratory and incorporated into a new radiative-transfer model. The albedo effects of each impurity were thus examined in isolation and compared. At the same time, we also undertook a sensitivity study with other bulk dust optical properties from previous literature to further test the potential role of mineral dusts in darkening the ice surface. Furthermore, by combining albedo measurements with incoming irradiance spectra and measurements of local melt rates, we estimated the radiative forcing and the proportion of melting that could be attributed to algae in areas of high and low algal biomass $\left(H_{\text {bio }}\right.$ and $\left.L_{\text {bio }}\right)$. At our field site we made UAV flights with a multispectral camera in order to map algal coverage at high spatial resolution. We achieved this by training a random-forest (RF) algorithm on our field spectroscopy data to classify the ice surface into discrete categories including $H_{\text {bio }}$ and $L_{\text {bio. }}$. This enabled estimates of algal coverage in a $200 \times 200 \mathrm{~m}$ area at our field site. We then retrained our classifier for Sentinel-2 satellite imagery and used this to upscale further within the south-western region of the GrIS (to a $100 \times 100 \mathrm{~km}$ Sentinel-2 tile covering our field site and UAV image area). With these estimates of algal coverage from our remote-sensing imagery and calculations of the proportion of melting attributed to algae from our field data, we were able to estimate runoff attributed to algae using the runoff model by van As et al. (2017). The details of each stage of our methodology are provided in the following Sect. 2.2-2.10.

\subsection{Field site}

Experiments were carried out at the Black and Bloom Project field site $\left(67.04^{\circ} \mathrm{N}, 49.07^{\circ} \mathrm{W}\right.$; Fig. 1), near the Institute for Marine and Atmospheric research Utrecht (IMAU) Automatic Weather Station "S6" on the south-western Greenland Ice Sheet between 10 and 22 July 2017. We established a $200 \times 200 \mathrm{~m}$ area for UAV mapping (centred on $67.07789444^{\circ} \mathrm{N}, 49.350000^{\circ} \mathrm{W}$ ) where only essential access was allowed (e.g. for placing ground control points, GCPs, for geo-rectifying our UAV images) and sample removal was prohibited. We also delineated an additional adjacent $20 \times 200 \mathrm{~m}$ area that we referred to as the "sampling strip" in which we made spectral reflectance and albedo measurements paired with removal of samples for biological and mineralogical analyses, as detailed in the following sections. The sampling strip was subdivided into smaller subregions that were then systematically visited each day of our field season. This was necessary because ice surface samples were destructively removed for analysis and this method ensured that each area visited had not been disturbed by our presence on previous days. Some ancillary directional reflectance measurements were also made at the same field site between 15 and 25 July 2016 and appended to our training dataset for supervised classification (Sect. 2.8).

\subsection{Field spectroscopy}

At each site in our sampling strip, albedo was measured using an ASD (Analytical Spectral Devices, Colorado) FieldSpec Pro 3 spectroradiometer with an ASD cosine collector. The cosine collector was mounted horizontally on a $1.5 \mathrm{~m}$ crossbar levelled on a tripod with a height between 30 and $50 \mathrm{~cm}$ above the ice surface. The cosine collector was positioned over a sample surface, connected to the spectroradiometer using an ASD fibre optic. Following this, the spectroradiometer was controlled remotely from a laptop, meaning the operators could move away from the instrument to avoid shading it. Two upwards- and two downwards-looking measurements were made in close succession $(\sim 2 \mathrm{~min})$ to account for any change in atmospheric conditions, although the measurements presented were all made during constant conditions of clear skies at solar noon $\pm 2 \mathrm{~h}$. Each retrieval was the average of $>20$ replicates.

Immediately after making the albedo measurements, the cosine collector was replaced with a $10^{\circ}$ collimating lens, enabling a nadir view hemispheric conical reflectance factor (HCRF) measurement to be obtained. For HCRF mea- 


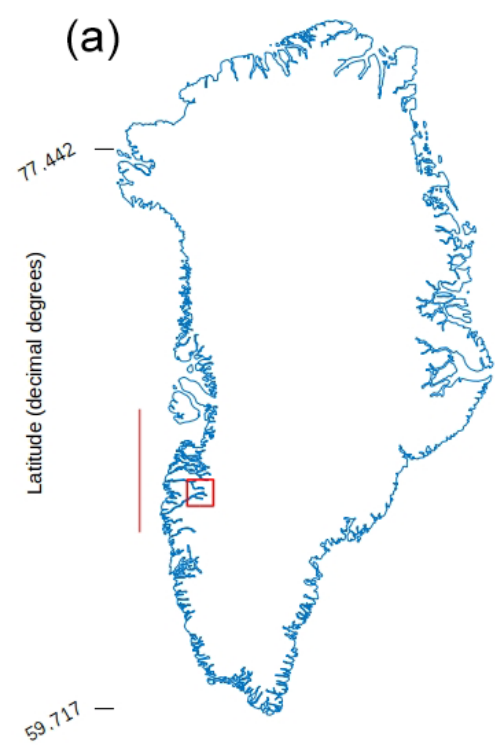

(b)

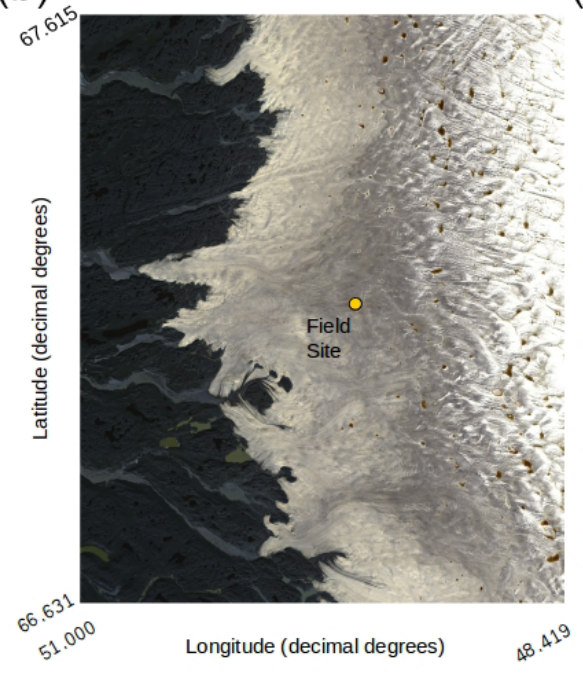

(c)

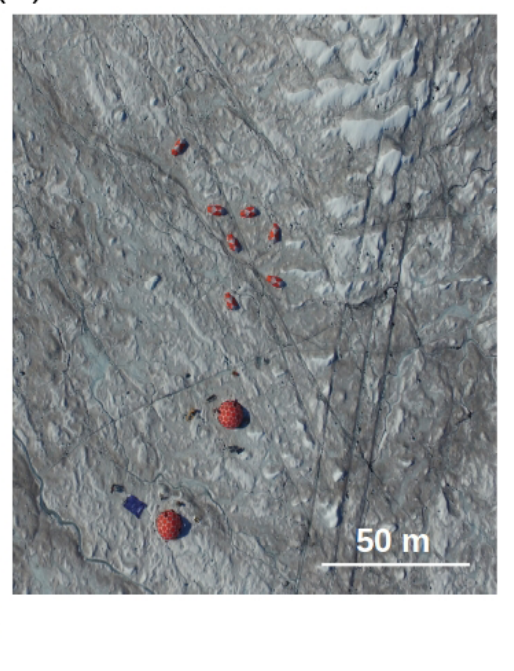

Figure 1. (a) Map of Greenland showing the bounding box of the Sentinel-2 tile (22WEV) containing our field site (red box) and the latitudinal extent of our runoff modelling (red line). The basemap was created using the MATLAB Arctic Mapping Toolbox (Greene et al., 2017). The Sentinel-2 tile outlined by the red box is shown in detail in (b) with the field site marked with a yellow dot. Sentinel-2 bands 2 , 3 and 4 were combined into a true-colour composite using GDAL (geographical data abstraction library, 2019), by the lead author. Panel (c) shows the area immediately surrounding the field camp as captured by a DJI Phantom Pro by the lead author.

surements the upwards-looking measurements were replaced with HCRF measurements of a flat Spectralon ${ }^{\circledR}$ panel with the spectroradiometer in reflectance mode. This protocol was followed for every sample surface, with both albedo and directional reflectance measurements taking less than $5 \mathrm{~min}$. We closely followed the methodology described by Cook et al. (2017b). Albedo is the most appropriate measurement for determining the surface energy balance, while the HCRF is closer to the measurements made by aerial remote sensing and less sensitive to stray light reflecting from surfaces other than the homogeneous patch directly beneath the sensor. We therefore used the albedo for energy balance calculations and the HCRF for remote-sensing applications in this study.

\subsection{Biological measurements}

Immediately following the albedo and HCRF measurements, ice from within the viewing area of the spectrometer was removed using a sterile blade and scooped into sterile WhirlPak bags, melted in the dark and immediately fixed with $3 \%$ glutaraldehyde. The samples were then returned to the University of Bristol and University of Sheffield where microscopic analyses were undertaken. Samples were vortexed thoroughly before $20 \mu \mathrm{L}$ was pipetted into a FuchsRosenthal haemocytometer. The haemocytometer was divided into $4 \times 4$ image areas. These were used to count a minimum of 300 cells to ensure adequate representation of species diversity (where possible, as some low-abundance samples had as few as one cell per haemocytometer). The volume of each image area was used to calculate cells per millilitre. Biovolume was determined by measuring the long and short axes of at least 10 cells from each species in each sample using the measure tool in the GNU Image Manipulation Program (GIMP). The morphology of the cells in the images was used to separate them into two species: Mesotaenium berggrenii and Ancylonema nordenskioldii. These dimensions were then used to calculate the mean volume of each species in each sample, assuming the cells to be circular cylinders (following Hillebrand, 1999, and Williamson et al., 2018). The average volume was multiplied by the number of cells for each species and then summed to provide the total biovolume for each sample.

\subsection{Mineral and algal optical properties and radiative-transfer modelling}

A new radiative-transfer package, BioSNICAR_GO, was developed for this study and was used to predict the albedo of snow and ice surfaces with algae and mineral dusts. We made a series of major updates and adaptations to the BioSNICAR model presented by Cook et al. (2017b). The package is divided into a bio-optical scheme wherein the optical properties of light-absorbing impurities and ice crystals can be calculated using Mie scattering (for small spherical particles such as black carbon or snow) or geometrical optics (for large and/or aspherical particles such as glacier algae, larger mineral dust particles, and large ice crystals) and a twostream radiative-transfer model based on SNICAR (Flanner et al., 2007), which incorporates the equations of Toon et 
al. (1989). A schematic of the model structure is provided in the Supplement (Sect. S1).

To incorporate glacier algae into BioSNICAR_GO, geometrical optics were employed to determine the singlescattering optical properties of the glacier algae, since they are large $\left(\sim 10^{3} \mu \mathrm{m}^{3}\right.$, making Mie calculations impractically computationally expensive) and best approximated as circular cylinders (Hillebrand, 1999; Lee and Pilon, 2003). Our approach is adapted from the geometric optics parameterization of van Diedenhoven (2014). The inputs to the geometric optics calculations are the cell dimensions and the complex refractive index. The imaginary part of the refractive index was calculated using a mixing model based upon Cook et al. (2017b), where the absolute mass of each pigment in the algal cells was measured in field samples. The absorption spectra for the algal pigments is provided in Fig. 2a. We updated the mixing model by Cook et al. (2017b) to apply a volume-weighted average of the imaginary part of the refractive index of water and the algal pigments so that the simulated cell looks like water at wavelengths where pigments are non-absorbing. We consider this to be more physically realistic than having cells that are completely nonabsorbing at wavelengths $>0.75 \mu \mathrm{m}$, especially since a water fraction $\left(X_{\mathrm{w}}\right)$ is used in the calculations to represent the non-pigmented cellular components of the total cell volume. This approach also prevents the refractive index from becoming infinite when the water fraction is zero, removing the constraint $0<X_{\mathrm{w}}<1$ from the bio-optical scheme in the original BioSNICAR model. Based upon experimental evidence in Dauchet et al. (2015) for the model species $C$. reinhardii, the real part of the refractive index has been updated from 1.5 (in Cook et al., 2017b) to 1.4. The absorption coefficients from which the imaginary refractive index is calculated are from Dauchet et al. (2015), apart from the purpurogallin-type phenol, whose optical properties were determined empirically (Fig. 2a). The calculated optical properties were added to the lookup library for BioSNICAR-GO for a range of cell dimensions. For the simulations presented in this study, we included two classes of glacier algae representing Mesotaenium berggrenii and Ancylonema nordenskioldii with length and diameter and also the relative abundance of each species matching the means measured in our microscopy described in Sect. 2.4. In simulations (Sect. S2) we found that ice albedo was relatively insensitive to the dimensions of the cells within a realistic range of lengths and diameters. This low sensitivity to cell length and diameter is likely because all of the cells considered here are large from a radiative-transfer perspective.

For mineral dusts, we took measured values for surface dust composition and particle size distribution (PSD) obtained at our field site from McCutcheon et al. (2020; hereafter, referred to as $\mathrm{McC}$ ). We then used complex refractive indices for the appropriate minerals obtained from the existing literature, mixed them using the Maxwell Garnett dielectric mixing approximation according to the measured mass fractions (after converting to volumetric fractions using the mineral densities), generated the single-scattering optical properties using a Mie scattering code and applied a weighted average using the PSD to obtain the bulk optical properties for the dust. Since the mineralogy of the dust varied between sites we generated three dust "scenarios". In the low-absorption scenario (LO-DUST) all the minerals were set to the minimum volume-fraction measured across all of McC's samples except for quartz, which comprised the remainder. In the high-absorption scenario (HI-DUST) all the minerals were set to their maximum measured volumefraction, apart from quartz, which comprised the remainder. Finally, in the mean scenario (MN-DUST) all the minerals were present with their volume fractions equal to the mean across all of the field samples. The mineralogy of each of these scenarios is described in Table 1. Refractive indices were not available for all of the individual minerals present in McC's analysis, so we represented the feldspar minerals using the refractive index for andesite (Pollack et al., 1973) and all pyroxenes with the refractive index for enstatite (Jäger et al., 2003), and, in the absence of a refractive index for amphibole phases, we used the refractive index for the similarly green mineral olivine (OCDB, 2002). Refractive indices for all other minerals were available (Rothman et al., 1998; Roush et al., 1991; Pollack et al., 1973; Egan and Hilgeman, 1983; Nitsche and Fritz, 2004).

The ice optical properties in BioSNICAR-GO were also calculated using a parameterization of geometric optics adapted from van Diedenhoven et al. (2014). A geometrical optics approach to generating ice optical properties was chosen because it enables arbitrarily large ice grains with a hexagonal columnar shape to be simulated, in order to better estimate the albedo of glacier ice where grains are large and aspherical. While the real ice surface is composed of irregularly shaped and sized grains, this approach enabled us to simulate our field spectra much more accurately and circumvented the requirements that individual grains be small and spherical in the case of the Lorenz-Mie approach. The optical properties of the ice grains were modelled using refractive indices from Warren and Brandt (2008). The radiative-transfer model is a two-stream model described in full in Cook et al. (2017b) and Flanner et al. (2007). For the radiative-transfer modelling presented in this study, the following model parameters were used: diffuse illumination; ice crystal side-length and diameter per vertical layer $=3,4,5$, 8 , and $10 \mathrm{~mm}$; layer thicknesses $=0.1,1,1,1$ and $1 \mathrm{~cm}$; underlying surface albedo $=0.15$; and layer densities $=500$, $500,600,600$ and $600 \mathrm{~kg} \mathrm{~m}^{-3}$. These ice physical properties were chosen to reduce the absolute error between the simulated albedo for ice without any impurities ("clean ice") and our mean field-measured clean-ice spectrum.

To realistically simulate measured dust and algal mass loadings on the ice surface, we took measured values for $H_{\text {bio }}$ field samples. For mineral dusts we took the mean and maximum mineral mass mixing ratios from $\mathrm{McC}$. They mea- 

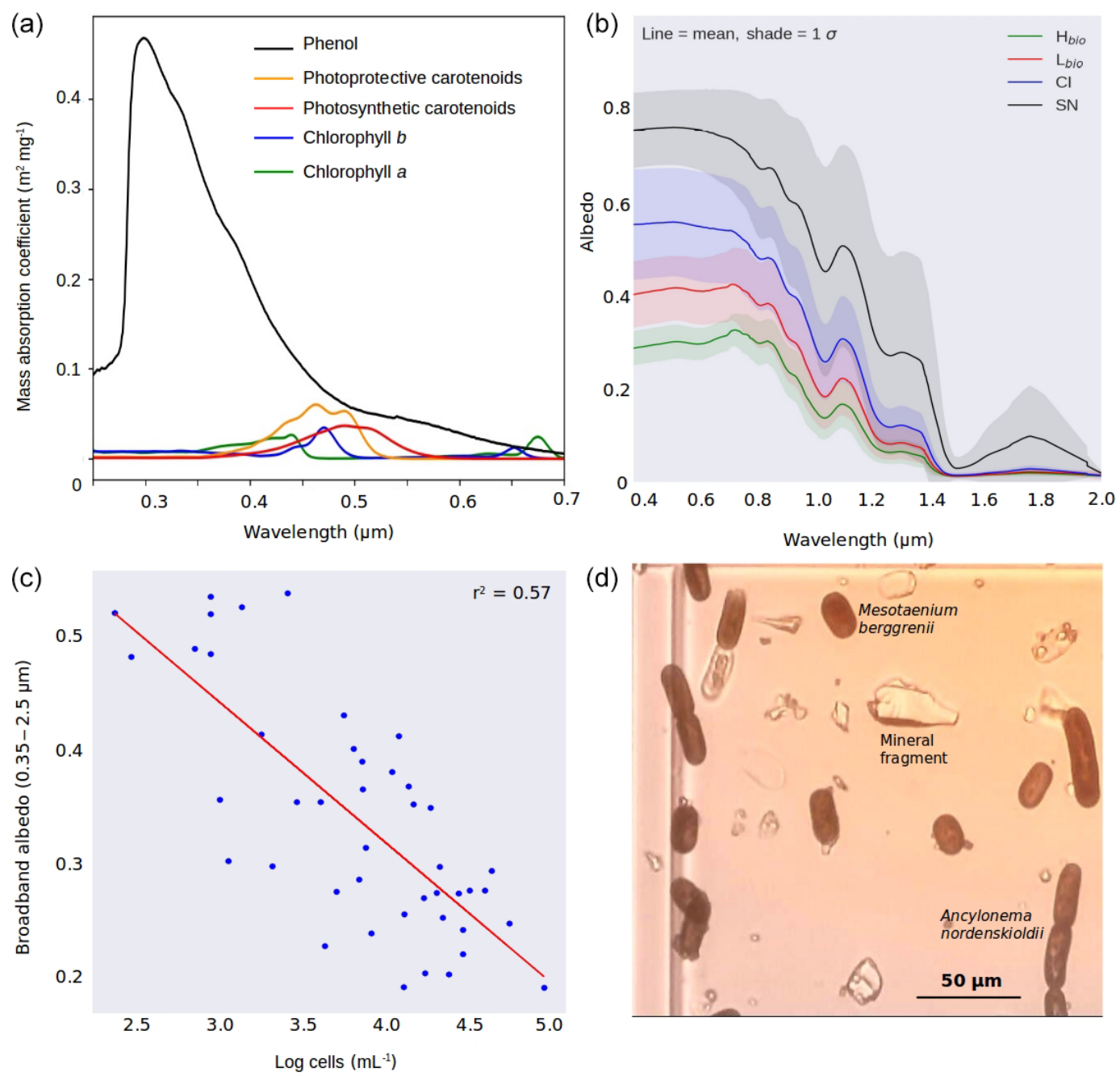

Figure 2. (a) Mass absorption coefficients of the major algal pigments including the purpurogallin-type phenol. (b) Measured spectral albedos for each surface type ( $H_{\text {bio }}$ is heavy biomass loading, $L_{\text {bio }}$ is light biomass loading, $C I$ is clean ice and $\mathrm{SN}$ is snow). (c) Plot showing the natural logarithm of cell abundance against broadband albedo. (d) Microscope image showing examples of both algal species and mineral fragments from a melted $H_{\text {bio }}$ sample.

Table 1. Composition of each mineral dust "scenario" in percent of total by volume.

\begin{tabular}{lrrrrrrr}
\hline & \multicolumn{7}{c}{ Fraction of total (\% by volume) } \\
\cline { 2 - 8 } Scenario & Quartz & Andesite & Olivine & Enstatite & Kaolinite & Illite & Muscovite \\
\hline HI-DUST & 3.42 & 67.12 & 10.53 & 8.42 & 3.36 & 1.70 & 5.46 \\
LO-DUST & 45.39 & 50.67 & 3.31 & 0.64 & 0 & 0 & 0 \\
MN-DUST & 24.19 & 61.03 & 6.95 & 3.90 & 1.37 & 0.19 & 2.37 \\
\hline
\end{tabular}

sured $394 \pm 194 \mu \mathrm{g}_{\mathrm{LAP}} \mathrm{mL}_{\mathrm{ice}}{ }^{-1}$, of which $\sim 95 \%$ was inorganic, giving mean and maximum mineral dust loadings of 373 and $567 \mu \mathrm{g}_{\mathrm{LAP}} \mathrm{mL}_{\mathrm{ice}}{ }^{-1}$. Assuming $1 \mathrm{~mL}$ of ice to weigh $0.917 \mathrm{~g}$, this gives mean and maximum mass mixing ratios of 342 and $519 \mu \mathrm{g}_{\text {dust }} \mathrm{g}_{\text {ice }}{ }^{-1}$. For glacier algae we calculated mass mixing ratios by taking the mean cell volume across all cells in our microscope images, converting to per-cell mass using a constant cell density $\left(0.87 \mathrm{~g} \mathrm{~cm}^{-3} ; \mathrm{Hu}, 2014\right)$ and multiplying by our mean and maximum $H_{\text {bio }}$ cell abundance. This gave mean and maximum mass mixing ratios of 349 and $646 \mu \mathrm{g}_{\text {algae }} \mathrm{g}_{\text {ice }}{ }^{-1}$. We also varied the mass mixing ratios over a range of hypothetical values to study the sensitivity of ice surface albedo to dust and glacier algae. Glacier algae and each of the mineral dusts (LO-DUST, HI-DUST, MN- 
DUST) were added individually to the upper $0.1 \mathrm{~cm}$ layer in mixing ratios of $10,100,500$ and $1000 \mu \mathrm{g}_{\mathrm{LAP}} \mathrm{g}_{\text {ice }}{ }^{-1}$, plus the mean and maximum measured mass mixing ratios for dust and algae, to quantify their effects on the surface albedo. We also ran a sensitivity study where we repeated the simulations with two other dust types, sourced from previous literature, with contrasting mineralogies to our field site.

\subsection{Empirical measurement of mineral dust reflectance}

For two samples of local mineral dusts obtained from $H_{\text {bio }}$ sites, we chemically removed the organic matter and measured the PSD using scanning electron microscopy (full details in Sect. S3). The chemical cleaning method avoided the artificial "reddening" of the mineral dust sample associated with removing organic matter by ignition. We then arranged the mineral dust samples into an optically thick layer on a microscope slide and pressed them tightly against the open aperture of a Thorlabs IS200-4 integrating sphere to measure their reflectance. The other apertures were covered with SM05CP2C caps and the sample reflectance was measured using the same ASD Field Spec Pro 3 as was used for field measurements.

\subsection{Radiative forcing and biological melt acceleration}

The biological radiative forcing was calculated by first differencing the albedo for algal surfaces and the albedo for clean ice surfaces measured at our field site. This gives the difference in albedo between the clean and algal ice surfaces, $\alpha_{\text {diff }}$. The product of each $\alpha_{\text {diff }}$ and the incoming irradiance, $I^{*}$, provided the instantaneous power density $\left(\mathrm{PD}_{\mathrm{alg}}\right)$ absorbed by the algae. We assume that photosynthetic processes utilize $5 \%$ of this absorbed energy - at the upper end of a realistic range for photosynthetic microalgae (Blankenship et al., 2011; Masojídek et al., 2013). The remainder of $\mathrm{PD}_{\mathrm{alg}}$ is conducted into the surrounding ice, giving the instantaneous radiative forcing due to algae $\left(\mathrm{IRF}_{\mathrm{alg}}\right)$. Since these cells are coloured by the purple purpurogallin pigment, we assume the reflective radiative forcing to be negligible, as demonstrated by Dial et al. (2018). $\mathrm{IRF}_{\text {alg }}$ was calculated at hourly intervals using incoming irradiance simulated for our field site using the PVSystems solar irradiance program (https://pvlighthouse.com.au, last access: July 2019) at $1 \mathrm{~nm}$ spectral resolution, following Dial et al. (2018). The radiative forcing was assumed to be constant between each $1 \mathrm{~h}$ time step, meaning the radiative forcing over $1 \mathrm{~h}\left(\mathrm{HRF}_{\mathrm{alg}}\right)$ could be calculated by multiplying $\mathrm{IRF}_{\mathrm{alg}}$ by $3600 \mathrm{~s} \mathrm{~h}^{-1}$, assuming that instantaneous radiative forcing is equal to radiative forcing per second. Daily radiative forcing due to algae $\left(\mathrm{RF}_{\mathrm{alg}}\right)$ was then calculated as the sum of $\mathrm{HRF}_{\text {alg }}$ between 00:00 and 23:00 UTC.

To calculate the algal contribution to melting $\left(M_{\mathrm{alg}}\right)$, $\mathrm{IRF}_{\text {alg }}$ was multiplied by $10^{4}$ to convert the radiative forcing from units of $\mathrm{W} \mathrm{m}^{-2}$ to $\mathrm{W} \mathrm{cm}^{-2}$ and then divided by the la- tent heat of fusion for melting ice $\left(334 \mathrm{~J} \mathrm{~g}^{-1}\right)$ and integrated over the entire day as described above. This provided a value for the amount of melting caused by the presence of algae per day assuming the cold content of the ice to be depleted. We calculated uncertainty by running these calculations for every possible combination of our measured algal and clean ice spectra and calculating the mean, standard error, and standard deviation of the pooled results.

We corroborated these estimates using a point surface energy balance model (Brock and Arnold, 2000; Tedstone, 2019). This model predicts melting in millimetres of water equivalent given local meteorological data and information about the ice surface albedo and roughness. We ran this model with the albedo set equal to the broadband albedo for each clean ice $(\mathrm{CI})$, heavy biomass $\left(H_{\text {bio }}\right)$ and light biomass $\left(L_{\text {bio }}\right)$ spectrum in our field measurements. The hourly meteorological data for 21 July 2017 used to force the model were from a Delta-T GP1 automatic weather station positioned at our field site. The difference in predicted melt between the algal surfaces and the clean ice surfaces provided the melt attributed to the presence of algae. As for the radiative forcing calculations, the uncertainty was calculated by running the energy balance model for every possible combination of algal and clean ice spectra and calculating the mean, standard error, and standard deviation of the pooled results.

\subsection{UAV and Sentinel-2 remote sensing}

Having quantified algal melt acceleration in localized patches using the methods described in Sect. 2.2-2.6, we then used a multispectral camera mounted to a UAV to quantify algal coverage across a $200 \times 200 \mathrm{~m}$ area at our field site. This sample area was kept pristine throughout the study period to minimize artefacts of our presence appearing in the UAV imagery. Inside the sampling area we placed fifteen $10 \times 10 \mathrm{~cm}$ ground control points (GCPs), whose precise location was measured using a Trimble differential GPS. At these markers we also made ground spectral measurements using an ASD-Field Spec Pro 3 immediately after each flight. The UAV itself was a Steadidrone Mavrik-M quadcopter, onto which we integrated a MicaSense Red-Edge multispectral camera. The camera is sensitive in five discrete bands, with centre wavelengths of $475,560,668,717$, and $840 \mathrm{~nm}$ and bandwidths of $20,20,10,10$, and $40 \mathrm{~nm}$, respectively. The horizontal field of view was $47.2^{\circ}$ and the focal length $5.4 \mathrm{~mm}$. The camera was remotely triggered through the autopilot, which was programmed along with the flight coordinates in the open-source software Mission Planner (Osborne, 2019). Images were acquired at approximately $2 \mathrm{~cm}$ ground resolution with $60 \%$ overlap and $40 \%$ sidelap. The flights were less than $20 \mathrm{~min}$ long and at an altitude of $30 \mathrm{~m}$ above the ice surface.

We applied radiometric calibration and geometric distortion correction procedures to acquired imagery following MicaSense procedures (Micasense, 2019). We then con- 
verted from radiance to reflectance using time-dependent regression between images of the MicaSense Calibrated Reflectance Panel acquired before and after each flight (i.e. a regression line was computed between the reflectance of the white reference panel at the start and end of the flight and used to quantify the change in irradiance during the flight). Finally, the individual reflectance-corrected images were mosaicked using AgiSoft PhotoScan following procedures developed by the United States Geological Survey (USGS, 2017), yielding a multi-spectral ortho-mosaic with $5 \mathrm{~cm}$ ground resolution, georectified to our GCPs. There was generally close agreement between the ground, UAV and satellite-derived albedo, although there are some differences that we believe to be the result of different radiometric calibration techniques for satellite, UAV and ground measurements, and the differing degrees of spatial integration have been examined in detail in Tedstone et al. (2019).

To upscale further, we used multispectral data from the Copernicus Sentinel-2 satellite. We selected the $100 \times 100 \mathrm{~km}$ tile covering our field site (T22WEV) on the closest cloud-free day to our UAV flight on 21 July. The L1C product was downloaded from SentinelHub (Sinergise, Slovenia). The L1C product was processed to L2A using the European Space Agency (ESA) Sen2Cor processor, including atmospheric correction and reprojection to $20 \mathrm{~m}$ resolution.

\subsection{Supervised classification algorithms and albedo mapping}

To map and quantify spatial coverage of algae over the ice sheet surface we employed a supervised classification scheme. A random forest (RF) classifier was trained on the field spectra collected on the ice surface (see Sect. 2.3) and then applied to multispectral images gathered by the UAV and Sentinel-2. We also included spectra obtained at the same field site in July 2016 to our training set, giving a total of 231 labelled spectra. A schematic of the classification workflow is provided in Sect. S4. Our HCRF measurements were first reduced to reflectance values at five key wavelengths coincident with the centre wavelengths measured by the MicaSense Red-Edge camera mounted to the UAV (blue: 0.475; green: 0.560; red: 0.668; red edge: 0.717; NIR: $0.840 \mu \mathrm{m}$ ), yielding reflectance at each wavelength as a feature vector for the classifier (in this case the spectral response function of the camera was not accounted for). The classification labels were the surface type as determined by visual inspection: SN (snow), CI (clean ice), CC (cryoconite), WAT (water), $L_{\text {bio }}$ (low-biomass algae) and $H_{\text {bio }}$ (high-biomass algae). For the algal surface classes our visual assessment was corroborated by microscopy, as described in Sect. 2.2. This dataset was then shuffled and split into a training set $(80 \%)$ and a test set $(20 \%)$. The training set was used to train three individual supervised classification algorithms: Naive Bayes, k-nearest neighbours (KNN) and support vector machine (SVM). For the SVM, the parameters $\mathrm{C}$ and gamma were tuned using grid search cross validation. Two ensemble classifiers were also trained: a voting classifier that combined the predictions of each of the three individual classifiers and a RF algorithm. The performance of each classifier was measured using precision, accuracy, recall, and F1 score and also by plotting the confusion matrix and normalized confusion matrix for each classifier. In all cases the RF outperformed the other classifiers according to all available metrics (Sect. S5). The performance of the RF classifier was finally measured on the test set, demonstrating the algorithm's ability to generalize to unseen data outside of the training set. Overfitting is not usually associated with the RF classifier, and the strong performance on both our training and test sets confirms that the model generalizes well. For these reasons, we used the RF algorithm to classify our multispectral UAV and Sentinel-2 images. Training the classifier using data from field spectroscopy ensures the quality of each labelled data point in the training set, since our sampling areas were homogeneous and surface samples were analysed in the laboratory, circumventing issues of spatial heterogeneity and uncertainty in labelling that could lead to ambiguity for direct labelling of aerial images. Comparisons between the directional reflectance spectra gathered using the ASD field spectrometer and those measured using the UAV and Sentinel-2 are provided in Fig. 3. Simultaneously with the surface classification, we calculated the albedo in each UAV pixel using the narrowband to broadband conversion of Knap et al. (1999) applied to the reflectance at each of the five bands.

This protocol was repeated for Sentinel-2 imagery. Additional bands are available for use as feature vectors in the case of Sentinel-2. Directional reflectance data gathered using the ASD field spectrometer were reduced to only those nine wavelengths coincident with the centre wavelengths measured by Sentinel- 2 at $20 \mathrm{~m}$ ground resolution $(0.480$, $0.560,0.665,0.705,0.740,0.788,0.865,1.610,2.190 \mu \mathrm{m})$. Training on reduced hyperspectral data has several advantages over training directly on aerial multispectral data. First, the method is sensor agnostic because the classifier can be retrained with a different selection of wavelengths for other upscaling platforms, enhancing the reusability of the field measurements. Second, we have confidence in our labels because each sample has been analysed in a laboratory to confirm its composition, reducing label ambiguity. Finally, the limited field of view of the field spectrometer reduces errors arising from mixing of spectra from heterogeneous ice surfaces. Sentinel-2 imagery was masked using the MeASUREs Greenland Ice Mapping Project ice mask (Howat, 2017) to eliminate non-ice areas. Pixels with more than $30 \%$ probability of being obscured by cloud were masked using the Sentinel-2 L2A cloud product generated by the Sen2Cor processor. For the calculation of albedo in each pixel, the additional bands available in the Sentinel-2 images enabled the application of Liang et al.'s (2001) narrowband to broadband conversion. 

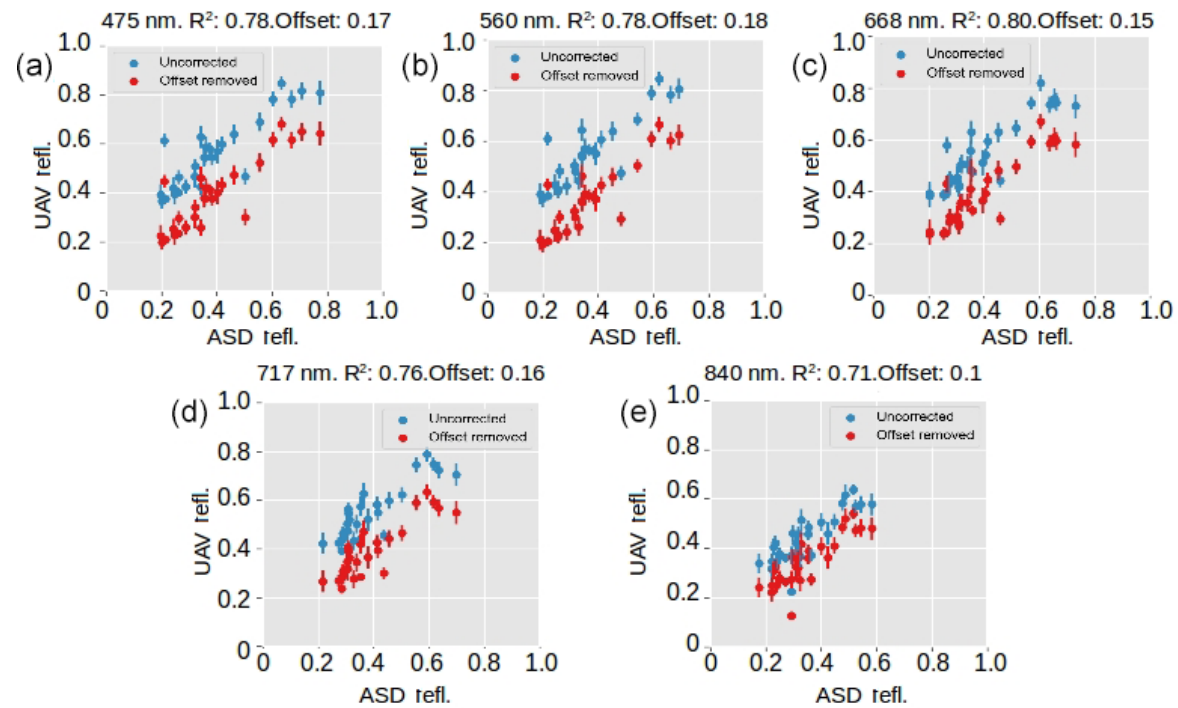

(f)
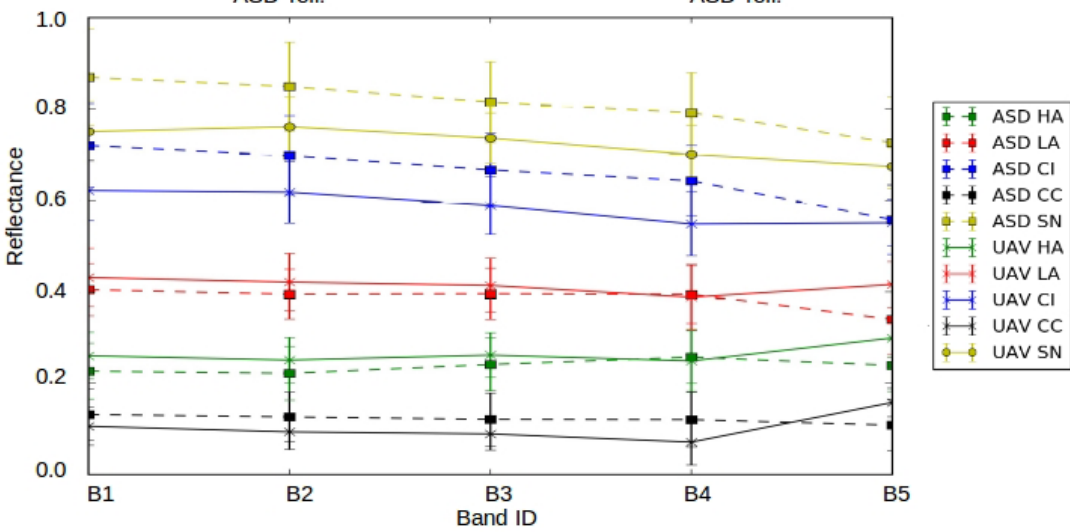

(g)

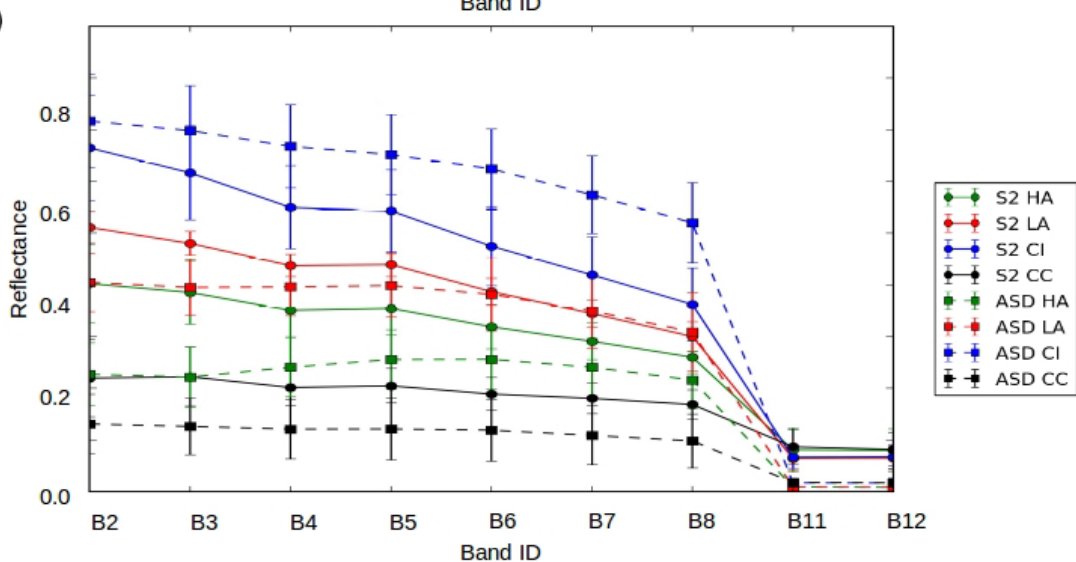

Figure 3. Inter-sensor comparisons. (a-e) Each UAV band reflectance plotted against ASD reflectance in uncorrected (blue) and corrected (red) form. The correction was applied to account for a systematic offset shown in the header for each plot. (f) Mean reflectance and \pm 1 standard deviation error bars at each spectral band for each surface class for the ASD field spectrometer and the UAV-mounted multispectral camera. (g) Mean reflectance and \pm 1 standard deviation error bars at each spectral band for each surface class for the ASD field spectrometer and Sentinel-2.

\subsection{Comparing 2016 and 2017}

In 2017, the GrIS dark zone had a relatively small spatial extent, high albedo and short duration in comparison to the other years in the MODIS record, particularly since 2007, whereas the dark zone was especially dark, widespread and prolonged in 2016 (Fig. 4; Tedstone et al., 2017). We therefore conducted a comparison between the algal coverage on the same dates in 2016 and 2017. First, we examined variations in the extent and duration of the dark zone, along with 
snow depths and snow clearing dates for the south-western ablation zone using MODIS, extending the time series of Tedstone et al. (2017). Bare ice was mapped by applying a threshold reflectance value $(R<0.60$ at $0.841-0.871 \mu \mathrm{m})$ to the MOD09GA Daily Land Surface Reflectance Collection 6 product. Within the bare-ice area, dark ice was mapped using a lower reflectance threshold $(R<0.45$ at $0.62-0.67 \mu \mathrm{m})$. The area of interest was the "common area" defined by Tedstone et al. (2017) bounded within the latitudinal range 65$70^{\circ} \mathrm{N}$ and is equal to that used by Wang et al. (2018). To measure the annual dark-ice extent (in $\mathrm{km}^{2}$ ) we counted the pixels that were dark for at least $5 \mathrm{~d}$ each year. The annual duration was defined at each pixel as the percentage of daily cloud-free observations made in each JJA (JuneJuly-August) period that were classified as dark. The timing of bare ice appearance was calculated from MODIS using a rolling window approach on each pixel (see Tedstone et al., 2017). The mean snow depths were extracted from outputs from the regional climate model MAR v3.8 (Fettweis et al., 2017) run at $7.5 \mathrm{~km}$ resolution forced by ECMWF ERAInterim reanalysis data (Dee et al., 2011). These data enabled a comparison of the extent and timing of dark ice in 2016 and 2017.

To examine algal coverage in each year we identified the Sentinel-2 tile covering our field site (22WEV) on the closest cloud-free date to the UAV flight day (21 July) in each year. These were 26 July 2017 and 25 July 2016. Since we were interested in the bare-ice zone, snow-covered pixels were omitted from the calculations.

\subsection{Runoff modelling}

Runoff at the regional scale was calculated using van As et al.'s (2017) surface mass balance (SMB) model, forced with local automatic weather station and MODIS albedo observations (van As et al., 2012, 2017). The model interpolates meteorological and radiative measurements from three PROMICE automatic weather stations on the K-transect (KAN-L, KAN-M and KAN-U) and bins them into $100 \mathrm{~m}$ elevation bands (0 to $2000 \mathrm{~m}$ a.s.l.). Surface albedo is from MODIS Terra MOD10A1 albedo and is averaged into the same $100 \mathrm{~m}$ elevation bins. For every $1 \mathrm{~h}$ time step, the model iteratively solves the surface energy balance for the surface temperature. If energy components cannot be balanced due to the $0{ }^{\circ} \mathrm{C}$ surface temperature limit, a surplus energy sink for melting of snow or ice is included. If surface temperature is greater than the melting point, the surplus energy is used for melting of snow or ice. When calculating turbulent heat fluxes, aerodynamic surface roughness for momentum was set to 0.02 and $1 \mathrm{~mm}$ for snow and ice, respectively (after van As et al., 2005, 2012; Smeets and Van den Broeke, 2008). We extrapolate modelled runoff across the south-western GrIS $\left(65-70^{\circ} \mathrm{N}\right)$ by deriving the areas of each elevation bin using the Greenland Ice Mapping Project (GIMP) digital elevation model (DEM; Howat et al., 2014). Total summer runoff from

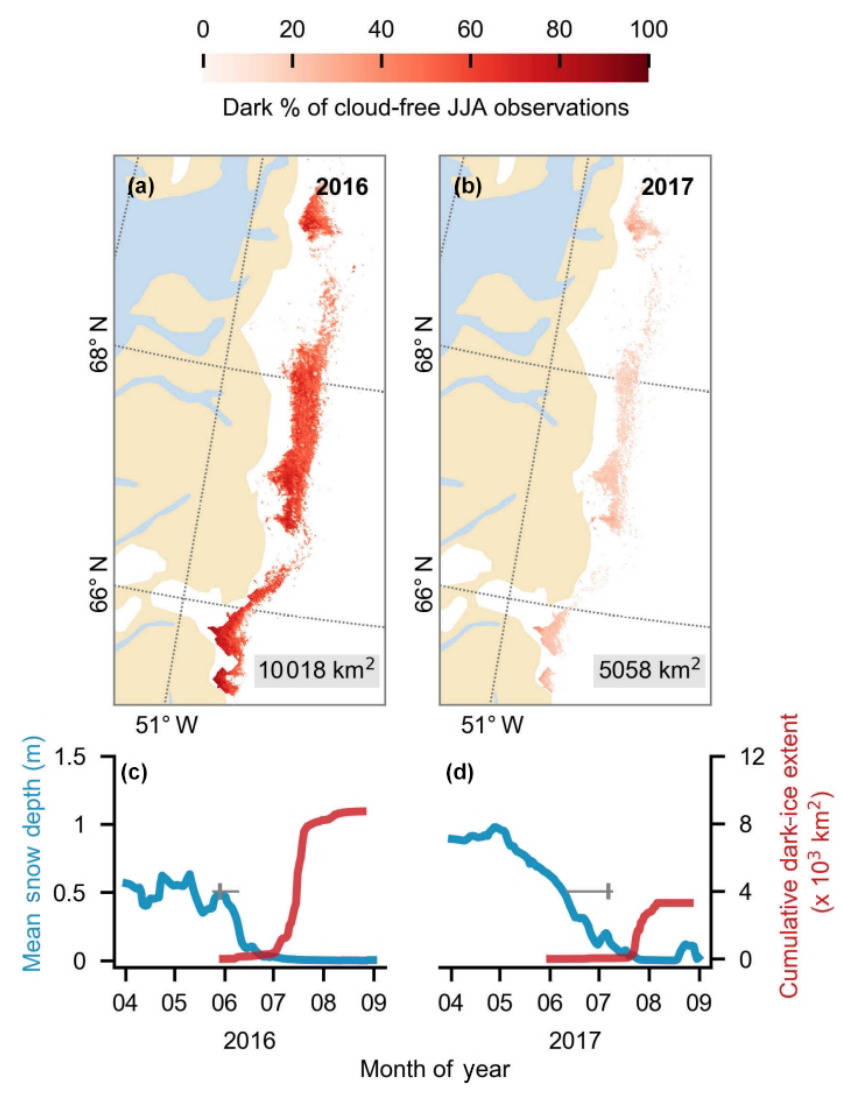

Figure 4. (a, b) Dark-ice duration on the south-western GrIS in summers 2016 and 2017, expressed as a percentage of the total daily cloud-free observations made during June-July-August (JJA). Each year is labelled with dark-ice extent. In each year, pixels that are dark for fewer than $5 \mathrm{~d}$ are not shown. (c, d) Average snow depth modelled by MAR (blue) and cumulative dark-ice extent observed by MODIS (red) (Tedstone et al., 2017) during April to August. Vertical bars (grey) denote median date of snow clearing derived from MODIS. Horizontal bars denote the interquartile range of the day of year of bare ice appearance. Tick marks denote the start of each month.

bare ice was calculated by summing runoff in elevation bins that had mean daily albedo of less than 0.60 . Total summer runoff from dark ice only was calculated in the same way but using a 0.39 threshold. The study by van As et al. (2017) compared the performance of the model with independent observations and found errors to be negligible in the bare-ice zone.

To determine the algal contribution to runoff, we used Eq. (1):

$R_{\mathrm{alg}}=R_{\mathrm{tot}} \times\left(\left(M_{H_{\mathrm{bio}}} \times C_{H_{\mathrm{bio}}}\right)+\left(M_{L_{\mathrm{bio}}} \times C_{L_{\mathrm{bio}}}\right)\right)$,

where $R_{\text {alg }}$ is the runoff due to algae, $R_{\text {tot }}$ is the total runoff from the bare-ice zone calculated using our runoff model, $M_{H_{\text {bio }}}$ and $M_{L_{\text {bio }}}$ are the mean percentage of total melt attributed to algae in $H_{\text {bio }}$ and $L_{\text {bio }}$ areas as calculated by our energy balance modelling described in Sect. 2.6, and $\mathrm{C}_{H_{\text {bio }}}$ 
and $C_{L_{\text {bio }}}$ are the proportion of $C_{\mathrm{tot}}$ comprised of $H_{\mathrm{bio}}$ and $L_{\text {bio }}$ areas in our UAV or Sentinel-2 images. As discussed later, the Sentinel-2 algal coverage estimate is conservative because it often fails to resolve $H_{\text {bio }}$ surfaces and therefore provides a lower bound on the runoff attributed to algae. An upper bound was therefore also calculated by assuming the spatial coverage derived from our UAV remote sensing - which can accurately distinguish $L_{\text {bio }}$ and $H_{\text {bio }}$ - surfaces is representative of the south-western dark zone. We were thereby able to estimate upper and lower limits for the runoff attributed to algal growth on the south-western ablation zone.

\section{Results and discussion}

\subsection{Algae reduce ice albedo}

The ice surfaces we studied were divided into four classes depending upon the algal abundance measured in the melted ice samples: high algal abundance $\left(H_{\text {bio }}\right)$, low algal abundance $\left(L_{\text {bio }}\right)$, clean ice $(\mathrm{CI})$ and snow $(\mathrm{SN})$. The algal abundance (cells $\mathrm{mL}^{-1}$ ) in each class was as follows: $H_{\text {bio }}=2.9 \times 10^{4} \pm$ $2.01 \times 10^{4} ; L_{\text {bio }}=4.73 \times 10^{3} \pm 2.57 \times 10^{3} ; \mathrm{CI}=625 \pm 381$; and $\mathrm{SN}=0 \pm 0(1 \mathrm{SD})$. These cell abundances were significantly different between the classes (one-way ANOVA: $F=$ $10.21 ; p=3 \times 10^{-5}$ ), which Bonferroni-corrected $t$ tests indicated to be due to variance between all four groups. The dominant species of algae were Mesotaenium berggrenii and Ancylonema nordenskioldii (Fig. 2d), confirming observations made by Stibal et al. (2017) and Williamson et al. (2018) in the same region. Their long, thin and approximately cylindrical morphology has been shown to be nearoptimal for light absorption (Kirk, 1976). The albedo of the ice surface also varied significantly between the surface classes (one-way ANOVA for broadband albedo: $F=$ 7.9; $p=2.8 \times 10^{-4}$ ), again with Bonferroni-corrected $t$ tests showing variance between all four groups (Sect. S6a, b). Greater algal abundance was associated with lower albedo, with the albedo reduction concentrated in the visible wavelengths (Fig. 2b) where both solar energy receipt and algal absorption peak (Cook et al., 2017b; Williamson et al., 2018), diminishing towards longer near infra-red (NIR: $>0.70 \mu \mathrm{m}$ ) wavelengths where ice absorption, represented by the effective grain size, is most likely to cause albedo differences (Warren, 1982). A strong inverse correlation (Pearson's $R=0.75, p=2.74 \times 10^{-9}$ ) was observed between the natural logarithm of algal cell abundance (cells $\mathrm{mL}^{-1}$ ) in the surface ice samples and broadband albedo (Fig. 2c). The linear regression coefficient of determination between the albedo and the natural logarithm of cell abundance was 0.57. It is unsurprising that the cell abundance does not account for all variation in albedo because there are also albedo-reducing effects related to the physical structure of the ice and presence of melt water (as demonstrated for snow by, for example, Warren, 1982). An inverse relationship was also ob- served between broadband albedo and biovolume (calculated as the sum of the products of the mean measured cell volumes and the cell counts for each algal species), but the coefficient of determination was lower $\left(r^{2}=0.42\right)$. This may well be the result of larger cells having a smaller effect on albedo than more numerous, smaller cells for a given total volume. The relationship between absorption and scattering coefficients and cell size may also not be straightforward for algal cells due to an increasingly important contribution to the cell optical properties from internal heterogeneity, organelles, cell walls and the pigment packaging effect in larger cells (Morel and Bricaud, 1981; Haardt and Maske, 1987).

The albedo of $H_{\text {bio }}$ and $L_{\text {bio }}$ surfaces is depressed in the visible wavelengths $(0.40-0.70 \mu \mathrm{m}$, Fig. $2 \mathrm{~b})$, creating a rededge spectrum commonly used in other environments as a marker for photosynthetic pigments (Seager et al., 2005) and for mapping algae over the GrIS by Wang et al. (2018). Chlorophyll $a$ has a specific absorption feature at $0.68 \mu \mathrm{m}$ which is hard to discern in the raw spectra but clear in the derivative spectra (Fig. 5a) for $H_{\text {bio }}$ and $L_{\text {bio }}$ but not CI and $\mathrm{SN}$. This feature has previously been described as "uniquely biological" (Painter et al., 2001) and supports the hypothesis that the albedo reduction observed in these samples is primarily due to algae. Our measurements therefore strongly indicate a biological role in reducing the albedo of the GrIS surface; however, to test that the lower broadband and spectral albedo observed on algal surfaces is primarily due to the presence of algal cells, it was also necessary to compare the albedo-reducing effects of the algae to that of local mineral dust.

\subsection{Algae have greater impact on albedo than mineral dust}

Radiative-transfer simulations demonstrated that at measured mass mixing ratios mineral dusts only have a very small $(<0.003)$ albedo-reducing effect at our field site on the south-western GrIS, whereas glacier algae reduce the ice albedo by up to 0.06 , not accounting for indirect albedoreducing feedbacks. The effect of adding the mean measured mass mixing ratio of MN-DUST to the clean ice was a very small albedo reduction of 0.002 (Table 2; Fig. 5b). In contrast, adding the mean measured mass mixing ratio of glacier algae reduced the albedo by 0.03 , preferentially in the short visible wavelengths in a similar way to our field-measured reflectance spectra (Table 2; Fig. 5b). This effect was greater when the mass mixing ratio was increased to the maximum measured values $\left(646 \mu \mathrm{g}_{\mathrm{algae}} \mathrm{g}_{\text {ice }}{ }^{-1}\right.$ and $\left.519 \mu \mathrm{g}_{\text {dust }} \mathrm{g}_{\text {ice }}{ }^{-1}\right)$ which caused an albedo reduction of 0.06 for glacier algae and 0.003 for MN-DUST. Changing the proportions of the minerals in our simulated local dusts had a very small effect on the albedo reduction. At the mean measured mass mixing ratio, HI-DUST reduced the albedo by just 0.0023 , while LO-DUST reduced the albedo by 0.0016 . Even with a mass mixing ratio of $1000 \mu g_{\text {dust }} g_{\text {ice }}{ }^{-1}$, the albedo reduction due 


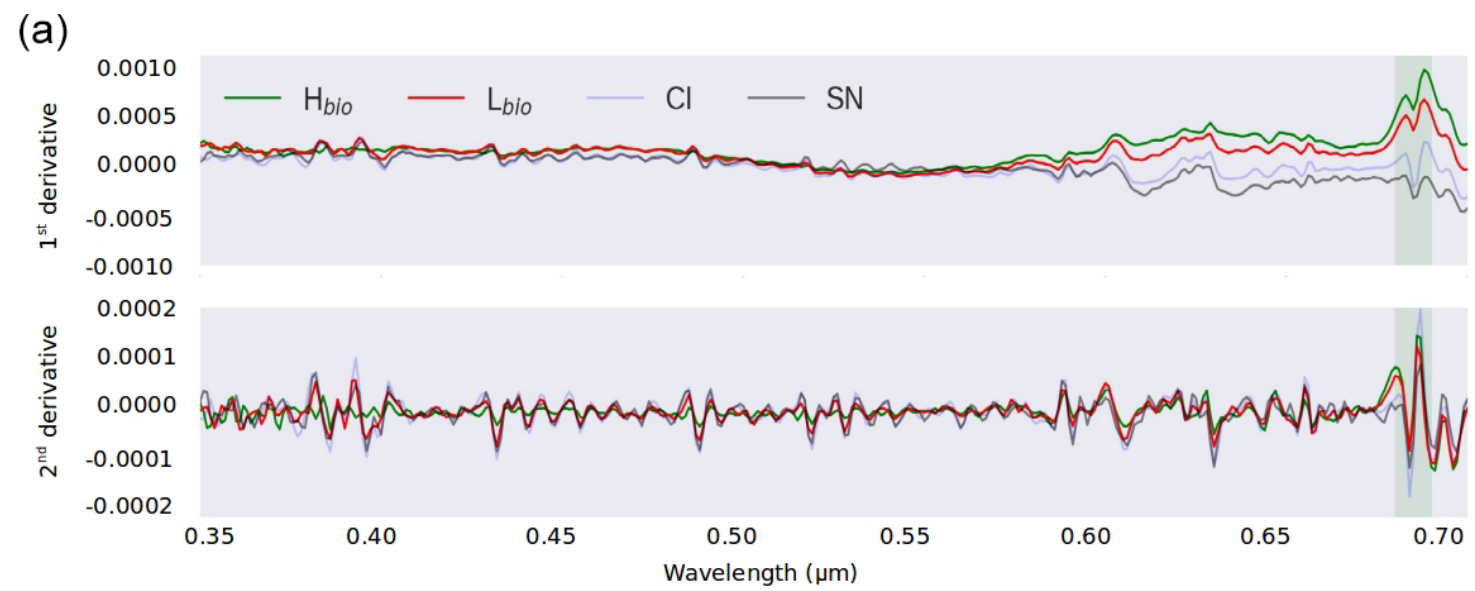

(b)

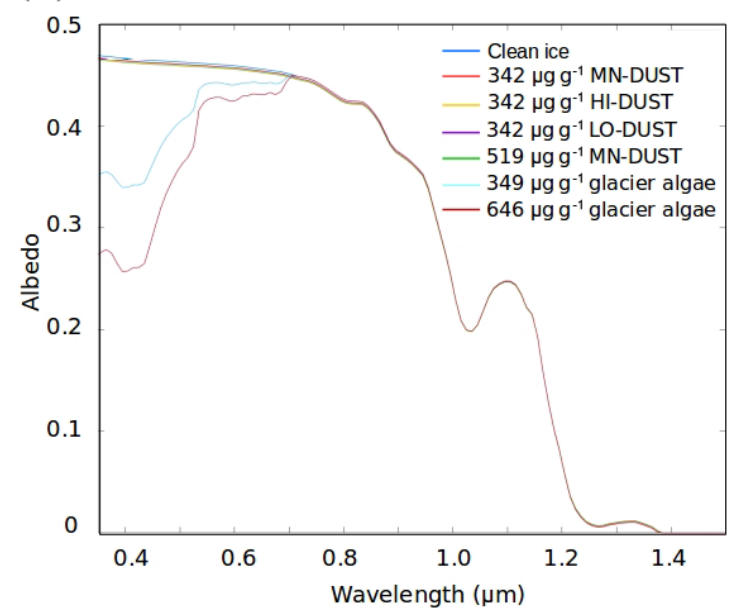

(c)

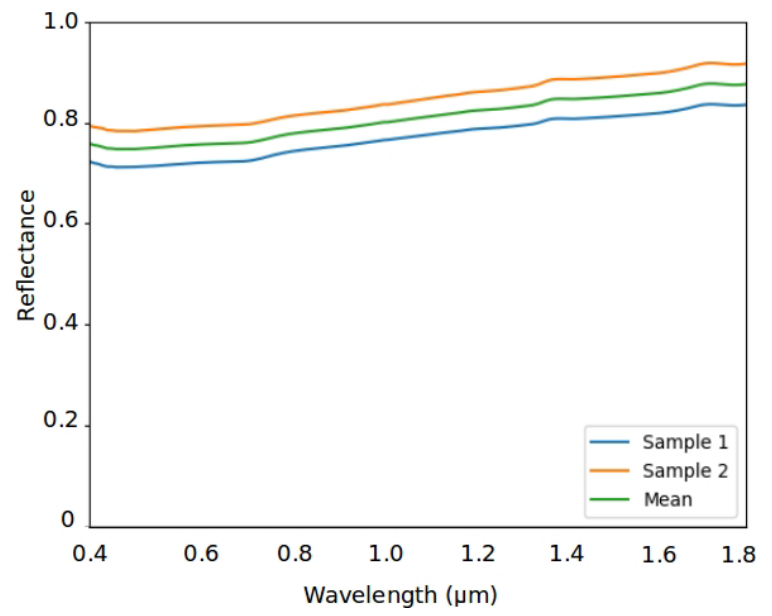

Figure 5. (a) The first and second derivative spectra for each surface class. (b) BioSNICAR-GO modelled spectral albedo for clean ice (blue) and ice with each of the simulated local dusts and algae in their measured mass mixing ratios in the upper $1 \mathrm{~mm}$. (c) Reflectance for an optically thick layer of two samples of the local mineral dust.

Table 2. Albedo change relative to clean ice caused by the addition of each LAP to the upper $1 \mathrm{~mm}$ of ice in a range of mass mixing ratios from 10 to $1000 \mu \mathrm{g}_{\mathrm{LAP}} \mathrm{g}_{\text {ice }}{ }^{-1}$.

\begin{tabular}{lrrrrr|rrrr}
\hline & \multicolumn{4}{c}{ Hypothetical mass mixing ratios $\left(\mu \mathrm{g}_{\mathrm{LAP}} \mathrm{g}_{\text {ice }}{ }^{-1}\right)$} & \multicolumn{4}{c}{ Measured mass mixing ratios $\left(\mu \mathrm{g}_{\mathrm{LAP}} \mathrm{g}_{\text {ice }}{ }^{-1}\right)$} \\
\cline { 2 - 10 } & 10 & 100 & 500 & 800 & 1000 & 342 & 349 & 519 & 646 \\
\hline Glacier algae & -0.0010 & -0.0110 & -0.0460 & -0.0670 & -0.0800 & -0.030 & -0.040 & -0.0487 & -0.056 \\
HI-DUST & -0.0001 & -0.0006 & -0.0030 & -0.0048 & -0.0060 & -0.0021 & -0.0023 & -0.0033 & -0.0039 \\
LO-DUST & -0.0001 & -0.0004 & -0.0021 & -0.0034 & -0.0042 & -0.0015 & -0.0016 & -0.0023 & -0.0028 \\
MN-DUST & $<0.0001$ & $<0.0001$ & -0.0020 & -0.0043 & -0.005 & -0.001 & -0.002 & -0.0029 & -0.0035 \\
\hline
\end{tabular}

to local mineral dusts was only $0.006,0.004$ and 0.005 for the HI-DUST, LO-DUST and MN-DUST, compared to 0.08 for glacier algae.

Across all our simulations, the broadband albedo-reducing power of glacier algae exceeded that of the local mineral dusts, often by several orders of magnitude. At fieldmeasured mass mixing ratios for heavily laden $H_{\text {bio }}$ surfaces, mineral dusts cannot account for the broadband albedo reduction observed in the field. This is consistent with the local mineralogy being dominated by weakly absorbing minerals with small grain sizes, as measured in our field sample (Figs. 5c, 6; Table 2). In Sect. S7 we demonstrate that these conclusions are robust to different dust types, including those with typically Saharan optical properties and dusts with vary- 


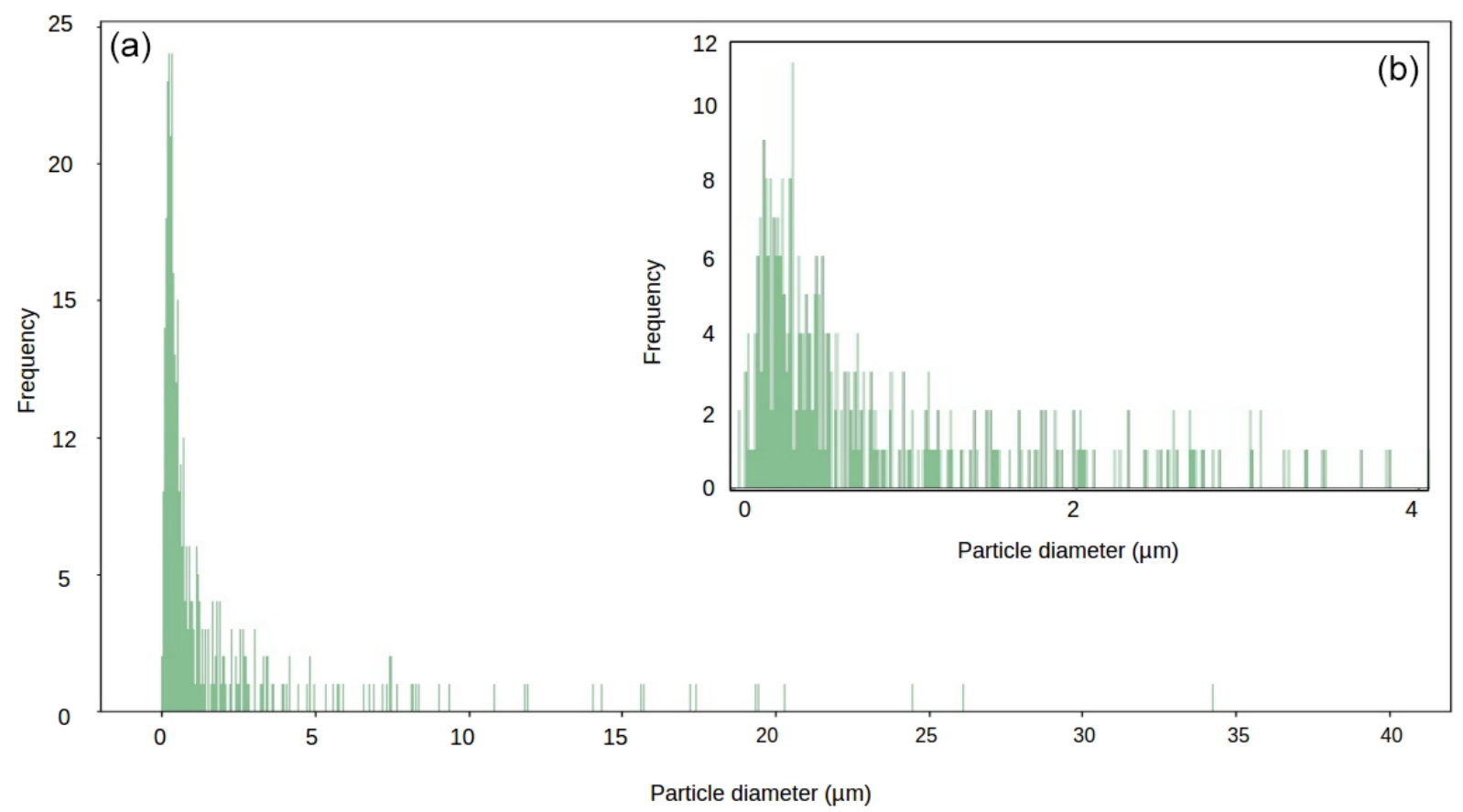

Figure 6. Particle size diameter for our local mineral dust sample (panel (b) shows magnification of $0-4 \mu \mathrm{m}$ range).

ing hematite concentrations. The radiative-transfer simulations do not account for feedbacks related to grain size and shape, near-surface meltwater accumulation, and the presence of other light absorbing particles, such as humic substances, that might modify the spectral reflectance and exacerbate the biological albedo reduction. Furthermore, the albedo-lowering effects of both the glacier algae and mineral dusts is reduced by the low albedo of the underlying ice. In simulations using smaller diameter, higher-albedo snow grains (whose optical properties were estimated using Mie theory) the albedo reduction caused by $1000 \mu \mathrm{g}_{\text {dust }}$ gice $_{\text {ice }}$ MN-DUST increased to $0.009,0.010$ and 0.012 for grains of diameter 1500, 1000 and $500 \mu \mathrm{m}$, respectively.

The small direct albedo-reducing effect from local minerals on the ice surface is seemingly in contrast to some previous studies, such as Wientjes et al. $(2010,2011)$ and Bøggild (2010); however, we highlight that neither of the Wientjes et al. $(2010,2011)$ studies directly measured the surface albedo or any optical properties of the mineral dusts retrieved from their GrIS sampling sites and only inferred mineralogical darkening from low spectral resolution MODIS data and the presence of a "wavy pattern" observed across the dark zone. We argue that while this may be indicative of geological outcropping onto the ablation zone, it does not necessarily follow that these minerals are responsible for surface darkening. In support of this, Wientjes et al. (2011) found strongly scattering and weakly absorbing quartz to be the dominant mineral in surface ice and speculated that biota may be having a darkening effect. Bøggild et al. (2010) found mineral dust to be an albedo reducer in Crown Prince Chris- tian Land $\left(80^{\circ} \mathrm{N}, 24^{\circ} \mathrm{W}\right)$, but this area is geologically and climatologically distinct from our field site and their transect only spanned $\sim 8 \mathrm{~km}$ from the ice sheet margin, being an area prone to local dust deposition. Overall, our study is consistent with previous studies that have identified that the local bare-ice mineral dust is poor in hematite and rich in weakly absorbing quartz and feldspar minerals (e.g. Tedesco et al., 2013). Tedesco et al. (2013) reported their dusts being redder than algae. However, their minerals were sourced from cryoconite, not the ice surface, where glacier algae are scarce and the biota is dominated by a rich consortium of other microbes that lack the characteristic pigmentation of glacier algae. Furthermore, Tedesco et al. (2013) reported an average of only $0.3 \%$ goethite in their Greenland cryoconite samples. This may have been present as hematite prior to their sample processing, which involved heating the samples to $500-1000^{\circ} \mathrm{C}$. This heating treatment likely oxidized Febearing mineral phases, thereby artificially introducing the observed reddening.

While these radiative-transfer simulations indicate that mineral dust is unlikely to be directly causing the albedo decline on the GrIS, they may still influence the ice albedo indirectly by acting as substrates for the formation of lowalbedo microbial mineral aggregates known as cryoconite granules, which are often found in quasi-cylindrical melt holes or scattered over ice surfaces (Wharton et al., 1985; Cook et al., 2015a) or by providing a nutrient source stimulating algal growth (Stibal et al., 2017). This is especially true because there is evidence in the previous literature that the dust present on the GrIS bare-ice surface is likely derived 
from a local source with no contribution from Asian dusts or volcanic ash (Wientjes et al., 2011) and that red minerals such as hematite, goethite and ilmenite are present only in very low concentrations (Wientjes et al., 2011; Tedesco et al., 2013; Sanna and Romeo, 2018) that would have a negligible effect on the ice albedo.

Therefore, we have demonstrated using empirical measurements and radiative-transfer modelling that glacier algae are potent albedo reducers on the south-western Greenland Ice Sheet and mineral dusts are not. These findings are consistent with several previous studies (Stibal et al., 2017; Yallop et al., 2012) that found mineral dust to be insignificant for explaining albedo variations in the same region.

\subsection{Indirect effects of algae}

Algae predominantly reduce the ice albedo in the visible wavelengths $(0.40-0.70 \mu \mathrm{m})$, whereas variations in the NIR result mainly from changes to ice grain radii and the presence of liquid water (Warren, 1982; Green et al., 2002). Variations in the NIR albedo between the surface classes therefore suggest that the lower albedo of algal surfaces is not explained entirely by enhanced absorption due to algae but also by the smoother, wetter ice surface with fewer opportunities for high-angle scattering of photons (Jonsell et al., 2003) compared to the well-drained and porous CI surfaces. The spatial and temporal development of the weathering crust is therefore an important control on ice albedo (Muller and Keeler, 1969; Jonsell et al., 2003). Algal growth is stimulated by melt, which can be enhanced by algal growth (Yallop et al., 2012; Ganey et al., 2017; Stibal et al., 2017; Cook et al., 2017a, b; Dial et al., 2018) - an example of a biocryomorphic process where biota alter the physical, chemical and hydrological conditions of the ice surface with beneficial consequences to the biota (Cook et al., 2015b).

\subsection{Algae enhance radiative forcing and melt}

Having determined that glacier algae reduce the ice surface albedo, we took an empirical approach to quantifying their impact upon energy balance following Ganey et al. (2017), which includes both direct albedo effects (enhanced absorption of shortwave solar radiation by the algal cells) and the indirect effects explained above. Integrated over the entire day, this indicated a daily mean biological radiative forcing of 116 and $65 \mathrm{~W} \mathrm{~m}^{-2}$ for $H_{\text {bio }}$ and $L_{\text {bio }}$ surfaces, respectively, similar to RFs for Alaskan snow algae calculated by Ganey et al. (2017). We used the biological radiative forcing integrated over the entire day and the latent heat of fusion for ice $\left(334 \mathrm{~J} \mathrm{~cm}^{-3}\right)$ to estimate $1.35 \pm 0.01$ (standard error, SE) $\mathrm{cm}$ w.e. of melting due to algae in $H_{\text {bio }}$ areas on 21 July. For $L_{\text {bio }}$ sites, biological melting on 21 July 2017 was $1.01 \pm 0.01(\mathrm{SE}) \mathrm{cm}$ w.e.

We corroborated this estimate using a point surface energy balance model (Brock and Arnold et al., 2000). The melt at- tributed to the presence of algae predicted by the energy balance modelling method was similar to that predicted using the radiative forcing method, with $1.37 \pm 0.48(\mathrm{SE}) \mathrm{cm}$ w.e. attributed to $H_{\text {bio }}$ and $0.95 \pm 0.41$ (SE) cm w.e. attributed to $L_{\text {bio. }}$. Expressing the melt attributed to algae as a proportion of the total melting in the algal sites gives $26.15 \pm 3.77 \%$ (SE) of the local melting attributed to algae in the $H_{\text {bio }}$ surfaces and $21.62 \pm 5.07 \%$ (SE) for $L_{\text {bio }}$ surfaces.

\subsection{Algae are widespread across the south-western ablation zone}

Our analyses demonstrate that algae have a dramatic darkening effect on the ice surface, leading to increased melting. However, the importance of this effect depends upon the spatial extent of the algal blooms over thousands of kilometres. To determine spatial coverage at our field site we classified multispectral images acquired from a UAV flown over a $200 \times 200 \mathrm{~m}$ area. The classified UAV image indicated that $78.5 \%$ of the area was covered by algal blooms, of which $61.1 \%$ was $L_{\text {bio }}$ and $17.4 \%$ was $H_{\text {bio }}$ (Table 3; Fig. 7). The high ground resolution of the imagery enabled a qualitative assessment of the algorithm performance by visual comparison between the classifier and the raw imagery (following Ryan et al., 2018a). The algorithm produced qualitatively realistic bloom shapes, correctly placed water in channels and individual cryoconite holes in their correct positions. The confusion matrix indicates that occasional misclassifications are generally between water and cryoconite (Sect. S8). This is unsurprising since both cryoconite and water have relatively flat spectral shapes with few spectral features and cryoconite is often found beneath pools of surface water. We also point out that our cryoconite spectral reflectance measurements were made with cryoconite filling the entire field of view of the spectrometer and thus best represent large cryoconite holes or dispersed cryoconite rather than surfaces peppered with many small holes. There was also some ambiguity between thin, wet snow and bare glacier ice, as these surfaces are spectrally similar. Nevertheless, these misclassifications affect a small area of the pixel and do not affect our estimate of algal bloom coverage.

We also classified Sentinel-2 satellite data (Fig. 7). The confusion matrices (Sect. S8) indicate similar misclassification types and frequencies to the UAV model. The predicted algal coverage was $58.87 \%$. $H_{\text {bio }}$ surfaces were much less common than $L_{\text {bio }}\left(H_{\text {bio }}=2.53 \% ; L_{\text {bio }}=56.54 \%\right.$; Table 3 ). The spatial coverage by algae was different in the Sentinel and UAV datasets especially for $H_{\text {bio }}$, likely because (a) the Sentinel-2 imagery includes ice that is outside of the dark zone, raising the overall reflectivity, and (b) even in the UAV image, which was retrieved from within the dark zone, $H_{\text {bio }}$ surfaces comprise just $17 \%$ of the ice surface and have a patchy distribution. The lowest-albedo surfaces - cryoconite and water - cover a small fraction $(<3 \%)$ of the total area in both UAV and Sentinel-2 images (Table 4), although we 
Table 3. Summary of the albedo for each surface class as predicted from our classified UAV image, the Sentinel-2 image for 2016 (S2 2016 ) and 2017 (S2 2017), and as measured using field spectroscopy (ASD Field Spec) at our field site in 2017 (we do not have cosine collector albedo measurements for water or cryoconite surfaces). The reported values are the mean, the standard deviation in brackets and the number of observations.

\begin{tabular}{lllllll}
\hline & WAT & CC & CI & $L_{\text {bio }}$ & $H_{\text {bio }}$ & SN \\
\hline UAV & $0.31(0.017)$ & $0.09(0.031)$ & $0.53(0.026)$ & $0.44(0.055)$ & $0.25(0.039)$ & $0.74(0.025)$ \\
& $n=160448$ & $n=154070$ & $n=2735603$ & $n=12098635$ & $n=3447152$ & $n=63647$ \\
\hline S2 2016 & $0.08(0.044)$ & $0.13(0.035)$ & $0.46(0.042)$ & $0.32(0.046)$ & $0.23(0.028)$ & $0.60(0.05)$ \\
& $n=52060$ & $n=272419$ & $n=6771763$ & $n=8388680$ & $n=1410095$ & $n=9924$ \\
\hline S2 2017 & $0.08(0.039)$ & $0.11(0.034)$ & $0.46(0.075)$ & $0.31(0.042)$ & $0.22(0.026)$ & $0.76(0.058)$ \\
& $n=174791$ & $n=258520$ & $n=5947314$ & $n=8740186$ & $n=2270206$ & $n=16333853$ \\
\hline ASD field spec & n/a & $\mathrm{n} / \mathrm{a}$ & $0.50(0.02)$ & $0.36(0.07)$ & $0.24(0.03)$ & $0.56(0.10)$ \\
& & $n=22$ & $n=28$ & $n=22$ & $n=5$ \\
\hline
\end{tabular}
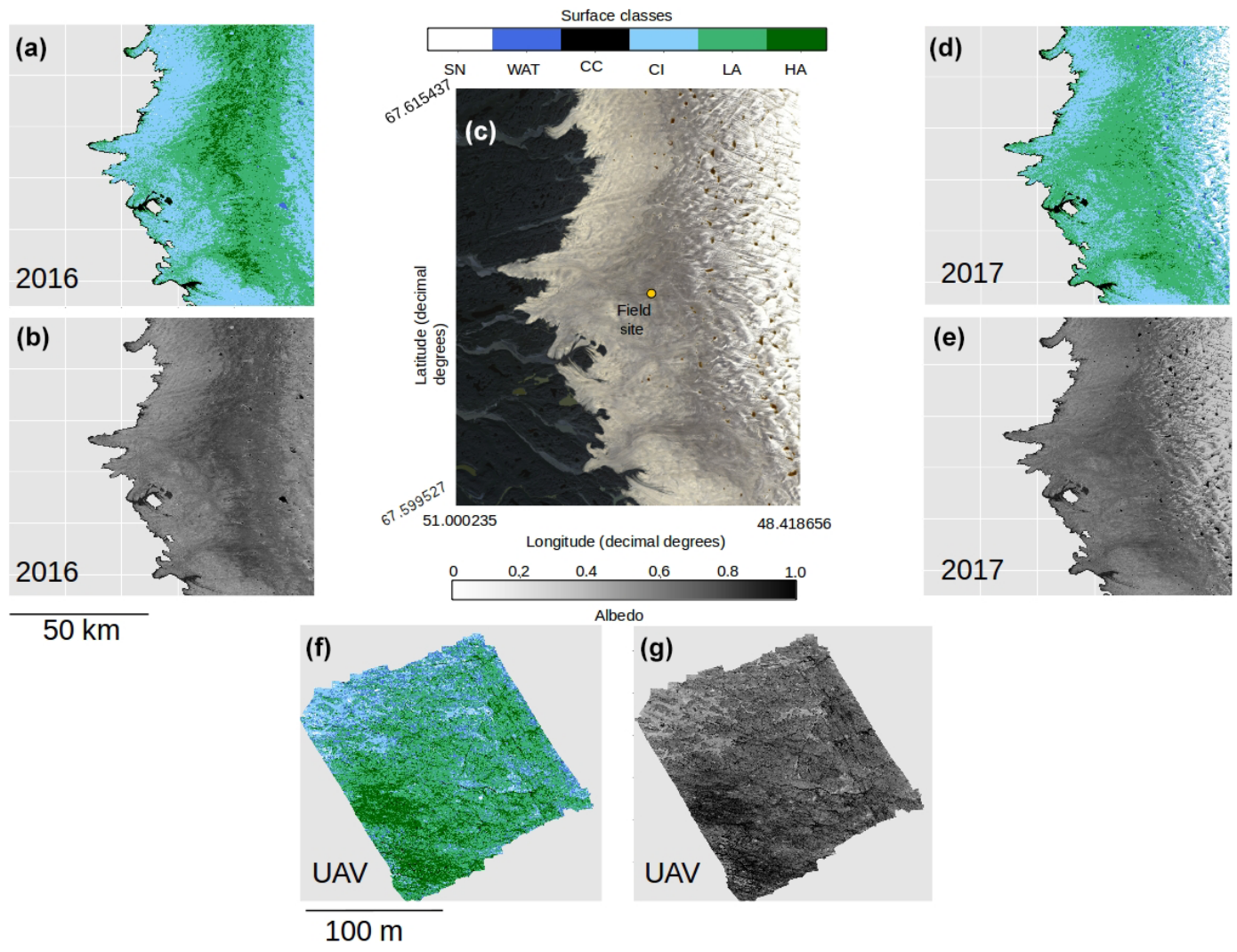

Figure 7. (a) Classified map of the area shown in (c) for 2016. (b) Broadband albedo map of the area shown in (c) for 2016. (c) RGB "true colour" image showing the Sentinel-2 tile covering our field site in the Kangerlussuaq area. (d) Classified map of the area shown in (c) for 2017. (e) Broadband albedo map of the area shown in (c) for 2017. (f) Classified map of a $200 \times 200 \mathrm{~m}$ area at the field site marked in (c) imaged using a UAV-mounted multispectral camera. (g) Broadband albedo map of a $200 \times 200 \mathrm{~m}$ area at the field site marked in (c) imaged using a UAV-mounted multispectral camera. Panels (a-e) all have pixel resolution of $20 \mathrm{~m}$ and use the base geographic coordinate reference system WGS84 and the Universal Tranvserse Mercator Projection (UTM) 22N. The scale bar beneath (b) is common to (a, b, d, e), and the scale bar beneath (f) is common to (f) and (g). 
Table 4. Percentage of each image covered by each surface type as predicted by our trained RF algorithm. Snow was removed from the calculation in the Sentinel-2 images to enable quantification of surface coverage in the bare-ice zone, i.e. below the snow line, only.

\begin{tabular}{lrrr}
\hline & UAV Image & Sentinel-2 (2016) & Sentinel-2 (2017) \\
\hline Total image area $\left(\mathrm{km}^{2}\right)$ & 0.04 & 10000 & 10000 \\
Total algae $(\%)$ & 78.5 & 57.99 & 58.87 \\
$H_{\text {bio }}(\%)$ & 17.4 & 8.35 & 2.54 \\
$L_{\text {bio }}(\%)$ & 61.08 & 49.65 & 56.33 \\
Cryoconite (\%) & 0.82 & 1.61 & 1.67 \\
Clean ice (\%) & 13.81 & 40.08 & 38.34 \\
Water (\%) & 0.78 & 0.31 & 1.13 \\
Snow (\%) & 6.09 & $\mathrm{n} / \mathrm{a}$ & $\mathrm{n} / \mathrm{a}$ \\
\hline
\end{tabular}

note that many individual cryoconite holes will not be detected as they are smaller than the spatial resolution of either Sentinel-2 or the UAV. The spatial coverage reported here from our multispectral UAV imagery is consistent with a k-nearest neighbours classification scheme applied to RGB (red, green, blue) imagery from a fixed wing UAV flight over the Kangerlussuaq region by Ryan et al. (2018a). They found up to $85 \%$ of the ice surface to be composed of "ice containing uniformly distributed impurities" in the same region of the dark zone in July 2014, which our observations confirm were dominated by algae. They also found $<2 \%$ of the ice surface to be cryoconite-covered and that water coverage was $<5 \%$ (except for a supraglacial lake in their imaged area). This analysis demonstrates that algae are a major component of the ice surface. The larger spatial coverage of algae observed in UAV images compared to Sentinel-2 images likely results from spatial integration occurring at the coarser spatial resolution associated with Sentinel-2 data, where pixels are likely to be classified as $\mathrm{CI}$ unless the majority of the pixel is covered by algae. Smaller $H_{\text {bio }}$ patches are rarely detected, presumably because they are unlikely to cover the majority of a $20 \mathrm{~m}$ pixel. The higher detection limit for algae with decreasing ground resolution makes our estimate of spatial coverage from Sentinel-2 conservative. We highlight that this will have a much larger effect on studies aiming to quantify cell abundance using Sentinel-3 where the ground resolution is $300 \mathrm{~m}$.

\subsection{Algae reduce the ice albedo across the south-western ablation zone}

There was a significant difference between the albedos of each surface class in all four datasets, consistent with the findings from our ground spectroscopy (Table 4). The albedo of each surface class is approximately consistent between the datasets, despite the variation in spatial coverage, giving confidence in the accuracy of our remote-sensing albedo retrievals and the classification algorithm. In the expansive areas where algae are present (Fig. 7), the ice albedo is on average 0.13 lower for $L_{\text {bio }}$ and 0.25 lower for $H_{\text {bio }}$ compared to clean ice (Table 4). This, combined with our ground-based spectroscopy, radiative forcing calculations, and radiative-transfer and energy balance modelling, provides robust evidence in support of algae having a significant melt-accelerating effect on the GrIS. We cannot yet explicitly separate mineral and biological effects, but our theoretical and empirical analyses indicate that (a) local mineral dust cannot explain the observed albedo reduction, (b) low-albedo areas had significantly elevated algal cell numbers relative to clean ice, (c) uniquely biological features were detectable in the spectra and derivative spectra for the lower-albedo sites, and (d) radiative-transfer models incorporating algal cells with realistic pigment profiles demonstrate the mechanism of albedo reduction. These observations confirm that supervised classification of $H_{\text {bio }}$ and $L_{\text {bio }}$ surfaces is indeed detecting surfaces with high algal loading and can be used to estimate algal bloom extent. Again, we point out that this estimate is conservative because there is certain to be glacier algae present in low numbers in some of the areas that are classified as clean and $H_{\text {bio }}$ patches are often smaller than the ground resolution of Sentinel-2, raising their detection limit (Tedstone et al., 2019). Furthermore, these calculations consider the total albedo-reducing effect, inclusive of ice structure and meltwater feedbacks, not only the direct light-absorbing effects of the algal biomass.

\subsection{Algae cause enhanced GrIS runoff}

We ran a SMB model forced with local automatic weather station and MODIS albedo observations (van As et al., 2012) to estimate $45.5 \mathrm{Gt}$ runoff from all bare ice and $33.8 \mathrm{Gt}$ from dark ice in 2017. We used the mean spatial coverage determined using our remote sensing in each year and our radiative forcing calculations that attributed $21.62 \pm 5.07$ (SE) \% of melting to algae in $L_{\text {bio }}$ sites and $26.15 \pm 3.77$ (SE) \% in $H_{\text {bio }}$ sites to generate estimates for the GrIS runoff caused by algal growth. We have provided upper and lower estimates based on our two remote-sensing datasets because, while our UAV is able to accurately map $H_{\text {bio }}$ and $L_{\text {bio }}$ surfaces, we cannot be certain that the spatial coverage derived from the $200 \times 200 \mathrm{~m}$ area is representative of the south-western dark zone. At the same time, our Sentinel-2 remote sensing under- 
estimates algal coverage because it includes ice outside of the dark zone and $H_{\text {bio }}$ patches are often too small to be resolved at $20 \mathrm{~m}$ pixel resolution (Tedstone et al., 2019). Therefore, we used the spatial coverage determined by our Sentinel-2 classification as a lower bound and spatial coverage determined by our UAV classification as an upper bound on our estimate of total runoff attributed to the presence of algae.

We found that in 2017 between 4.4 and $6.0 \mathrm{Gt}$ of ice loss could be attributed to the growth of algae, representing $10 \%-$ $13 \%$ of the total runoff from the south-western GrIS, with the lower estimate generated using algal coverage from Sentinel2 and the upper estimate generated using spatial coverage at our field site from our UAV. When the calculations were restricted to the dark zone only (i.e. excluding areas in the ablation zone not classified as "dark"), algal contributions to total runoff were up to $18 \%$. These calculations confirm that algal growth is an important factor in the contribution of the GrIS to global sea level rise. This contribution will increase if biologically darkened areas expand or a greater proportion of the ice is covered by high-biomass blooms under warmer climates. These observations therefore indicate that the omission of biological growth is leading current models to underestimate future GrIS contributions to sea level rise.

\subsection{Interannual variability and potential positive feedback}

MODIS data (Fig. 4) indicate that 2017 was a particularly high-albedo year when the dark zone was especially small and bright, whereas 2016 was a particularly low-albedo year where the dark zone was wider and darker than most years (Fig. 4a and b and Tedstone et al., 2017). Previous field evidence (Williamson et al., 2018) demonstrates that the ice was darkened by high concentrations of algae in 2016. In our Sentinel-2 remote-sensing tile (22WEV) the bare-ice zone was wider in $2016\left(6758 \mathrm{~km}^{2}\right)$ than in $2017\left(6205 \mathrm{~km}^{2}\right)$ and a larger area was covered with algae (on 25 July 2016, $3919 \mathrm{~km}^{2}$ was covered by algae compared to $3653 \mathrm{~km}^{2}$ on 28 July 2017). While the proportional total algal coverage was similar between the 2 years $(57.99 \%$ in 2016 and $58.87 \%$ in 2017), the proportion of the algal ice that was classified $H_{\text {bio }}$ was much higher in $2016(8.35 \%)$ compared to $2017(2.54 \%)$. The mean albedos and their standard deviations were very similar for each ice surface class in both years (Table 4). The runoff from the south-western GrIS bare ice (albedo <0.6) was $94.1 \mathrm{Gt}$ in 2016 , of which 67.6 was from dark ice (albedo <0.39). We estimate that $8.8-12.2 \mathrm{Gt}$ of this runoff was attributable to the growth of algae, representing $9 \%-13 \%$ of the total runoff from bare-ice sectors. The absolute values for runoff are therefore much higher but the proportion of the bare-ice total attributed to algae was approximately the same between the 2 years.

The snow line retreated further and earlier in 2016 compared to 2017, creating a wider bare-ice zone that existed for longer and was not transiently covered by summer snowfall events, whereas in 2017 a smaller bare-ice area was exposed later and was covered by $5-10 \mathrm{~cm}$ of snow several times during the summer (Fig. 4c, d). The more prolonged exposure of a larger bare-ice zone in 2016 enabled $L_{\text {bio }}$ surfaces to extend to higher elevations and biomass to accumulate to greater mass concentrations at lower elevations in summer 2016, explaining the greater $H_{\text {bio }}$ coverage. This indicates that the intensity of the algal bloom is a function of exposure time, as postulated by Tedstone et al. (2017) and Williamson et al. (2018). More prolonged exposure of larger ablation areas under a warming climate (Stroeve et al., 2013; Shimada et al., 2016; Tedesco et al., 2016; Tedstone et al., 2017) are likely to be prone to more spatially expansive, darker algal blooms that enhance melt rates, leading to a potential positive feedback that is not currently accounted for in surface mass balance models, whereby earlier exposure of bare ice leads to enhanced algal coverage, which will be able to accumulate higher biomass and accelerate melting. Melting in turn stimulates algal growth by liberating nutrients and liquid water.

\section{Conclusions}

Our measurements and modelling demonstrate that the growth of algae on the GrIS accelerates the rate of melting and increases the GrIS contribution to global sea level rise. Field spectra show a dramatic depression of the surface albedo in the visible wavelengths for surfaces contaminated by algae. Derivative analysis of the same spectra show uniquely biological absorption features and an inverse relationship was observed between biomass and surface albedo. We employ a novel radiative-transfer model to show that this albedo decline cannot be attributed to local mineral dusts. Radiative forcing calculations and an energy balance model predict that melting of glacier ice can be accelerated by $21.62 \pm 5.07$ (SE) \% for $L_{\text {bio }}$ surfaces and $26.15 \pm 3.77$ (SE) $\%$ for $H_{\text {bio }}$ surfaces. We demonstrate that the growth of algae occurs over a large proportion of the ablating area of the south-western GrIS by identifying algal blooms in remote-sensing data from a UAV and Sentinel-2, finding $78.5 \%$ of the surface within a $200 \times 200 \mathrm{~m}$ sample area at our field site to be covered by algae. Using Sentinel-2 we detected algae covering $57.99 \%$ of the Kangerlussuaq region in 2017 and $58.87 \%$ of the same region in 2016 . The spatial resolution of the sensor makes these conservative estimates, especially for $H_{\text {bio }}$ surfaces. Runoff modelling informed by our field measurements and remote-sensing estimate between 4.4 and $6.0 \mathrm{Gt}$ of runoff from the south-western ablation zone could be attributed to the growth of algae in summer 2017, representing $10 \%-13 \%$ of the total. Because 2017 was a particularly high-albedo year for the south-western GrIS, we also ran our analysis for the particularly low-albedo 2016 melt season. In 2016 a wider bare-ice zone was exposed for longer, and there was a concomitant increase in the extent 
of the algal bloom, more of which was classified as $H_{\text {bio }}$ (high biomass). The percentage algal contribution to southwestern GrIS runoff was approximately the same as in 2017 (9\%-13\%), but the absolute volume was much higher (8.8$12.2 \mathrm{Gt}$ ). This interannual comparison indicates the existence of a feedback because in years where snow retreats further and earlier, there is a larger and more prolonged area for algal bloom development where melting is enhanced, stimulating further algal growth. This study therefore demonstrates that algae are important albedo reducers and cause a melt-enhancing feedback across the south-western GrIS. The omission of these critical biological albedo feedbacks from predictive models of GrIS runoff is leading to underestimation of future ice mass loss and contribution to global sea level rise. This is particularly significant because larger ablation zones and longer growth seasons are expected in a future warmer climate.

Code and data availability. Codes and datasets used in this study are available at the following DOIs.

- BioSNICAR-GO code and data: https://doi.org/10.5281/zenodo.3564517 (Cook et al., 2020a).

- Ice surface classification codes: https://doi.org/10.5281/zenodo.3564529 (Cook et al., 2020b).

- Spectra processing codes: https://doi.org/10.5281/zenodo.2598219 (Cook, 2020).

- Field and associated data: https://doi.org/10.5281/zenodo.3564501 (Cook et al., 2020c).

Supplement. The supplement related to this article is available online at: https://doi.org/10.5194/tc-14-309-2020-supplement.

Author contributions. JMC developed the measurement protocol, gathered field measurements, analysed the data, wrote the main code, curated the data repository, produced the figures and wrote the manuscript. OMcA was instrumental in building and testing the UAV. AJT, CW, JM and SH gathered field data. CW provided advice regarding microscopy and biological sampling protocols, helped with experimental design, and led the empirical measurements of glacier algae pigmentation and absorption coefficients. AJT wrote the code for radiometric calibration of multispectral imagery from the UAV and post-processed the UAV images, derived 2016 and 2017 dark-ice extent from MODIS imagery, analysed MAR snow depth outputs, produced Fig. 4, translated the energy balance model into Python, and made significant contributions to the manuscript writing and experimental design. JM and SM provided cleaned mineral dust and PSD data to feed into the radiative-transfer model, and JM provided useful discussions regarding experimental design. MS provided DISORT modelling and estimates of mineral dust refractive indices. MF helped develop the bio-optical model. RB provided advice regarding field spectroscopy and helped measure mineral dust refractive indices in the laboratory. AJH helped develop the experimental design. AJH, JR and AM all provided advice on
UAV remote sensing. JR, DvA and AJH modelled runoff from the GrIS dark zone. AD provided microscopy images from field samples. Other authors contributed to field work and/or sample preparation and commented on the style and content of the final paper.

Competing interests. The authors declare that they have no conflict of interest.

Acknowledgements. Joseph M. Cook, Andrew J. Tedstone, Andrew J. Hodson, Christopher Williamson, Archana Dayal, Stefan Hofer, Andrew McGonigle, Alexandre M. Anesio, Tristram D. L. Irvine-Fynn, Edward Hanna, Marian Yallop and Martyn Tranter acknowledge funding from UK National Environmental Research Council large grant "Black and Bloom". Joseph M. Cook gratefully acknowledges the Rolex Awards for Enterprise, National Geographic and Microsoft ("AI for Earth") and NERC Standard Grant "MicroMelt". Liane G. Benning, Jenine McCutcheon and James B. McQuaid acknowledge funding from the UK National Environmental Research Council large grant "Black and Bloom", and Liane G. Benning and Sathish Mayanna acknowledge funding from the German Helmholtz Recruiting Initiative. Thomas Gribbin acknowledges the Gino Watkins Memorial Fund and Nottingham Education Trust. Greenland Analogue Project (GAP) weather station data are made available through the Programme for Monitoring of the Greenland Ice Sheet (http://www.promice.dk/home.html, last access: January 2020). MAR v3.8.1 regional climate model outputs used to estimate mean snow depth were provided by Xavier Fettweis. We thank Stephen Warren his for helpful comments that improved the manuscript.

Financial support. This research has been supported by the UK National Environmental Research Council (grant no. NE/M021025/1), the UK National Environmental Research Council (grant nos. NE/M020770/1, NE/S001034/1), and the German Helmholtz Recruiting Initiative (grant no. I-044-16-01).

Review statement. This paper was edited by Marco Tedesco and reviewed by Stephen Warren and one anonymous referee.

\section{References}

Bamber, J., Westaway, R. M., Marzeion, B., and Wouters, B.: The land ice contribution to sea level during the satellite era, Environ. Res. Lett., 13 063008, https://doi.org/10.1088/17489326/aac2f0, 2018.

Benning, L. G., Anesio, A. M., Lutz, S., and Tranter, M.: Biological impact on Greenland's albedo, Nat. Geosci., 7, 691, https://doi.org/10.1038/ngeo2260, 2014.

Blankenship, R. E., Tiede, D. M., Barber, J., Brudvig, G. W., Fleming, G., Ghirardi, M., Gunner, M. R., Junge, W., Kramer, D. M., Melis, A., Moore, T. A., Moser, C. C., Nocera, D. G., Nozik, A. J., Ort, D. R., Parson, W. W., Prince, R. C., and Sayre, R. T.: Comparing photosynthetic and photovoltaic efficiencies and rec- 
ognizing the potential for improvement, Science, 332, 805-809, 2011.

Bøggild, C. E., Brandt, R. E., Brown, K. J., and Warren, S. G.: The ablation zone in northeast Greenland: ice types, albedos and impurities, J. Glaciol., 56, 101-113, 2010.

Box, J. E., Fettweis, X., Stroeve, J. C., Tedesco, M., Hall, D. K., and Steffen, K.: Greenland ice sheet albedo feedback: thermodynamics and atmospheric drivers, The Cryosphere, 6, 821-839, https://doi.org/10.5194/tc-6-821-2012, 2012.

Brock, B. W. and Arnold, N. S.: A spreadsheet-based (Microsoft Excel) point surface energy balance model for glacier and snow melt studies, Earth Surf. Proc. Land., 25, 649658. https://doi.org/10.1002/1096-9837(200006)25:6<649::aidesp97>3.0.co;2-u, 2000.

Cook, J. M., Edwards, A., Irvine-Fynn, T. D. I., and Takeuchi, N.: Cryoconite: Dark biological secret of the cryosphere, Prog. Phys. Geog., 40, 66-111, https://doi.org/10.1177/0309133315616574, 2015a.

Cook, J. M., Edwards, A., and Hubbard, A.: Biocryomorphology: Integrating Microbial Processes with Ice Surface Hydrology, Topography, and Roughness, Front. Earth Sci., 3, 78, https://doi.org/10.3389/feart.2015.00078, 2015b.

Cook, J. M., Hodson, A. J., Taggart, A. J., Mernild, S. H., and Tranter, M.: A predictive model for the spectral "bioalbedo" of snow, J. Geophys. Res.-Earth Surf., 122, 434454, https://doi.org/10.1002/2016JF003932, 2017a.

Cook, J. M., Hodson, A. J., Gardner, A. S., Flanner, M., Tedstone, A. J., Williamson, C., Irvine-Fynn, T. D. L., Nilsson, J., Bryant, R., and Tranter, M.: Quantifying bioalbedo: a new physically based model and discussion of empirical methods for characterising biological influence on ice and snow albedo, The Cryosphere, 11, 2611-2632, https://doi.org/10.5194/tc-11-2611-2017, 2017b.

Cook, J. M.: Spectra Processing Codes, Zenodo, https://doi.org/10.5281/zenodo.2598219, last access: January 2020.

Cook, J. M., Williamson, C., Tedstone, A. J., McCutcheon, J., and Flanner, M.: BioSNICAR-GO, Zenodo, https://doi.org/10.5281/zenodo.3564517, last access: January 2020a.

Cook, J. M., Tedstone, A. J., Williamson, A. J., and McCutcheon, J.: Ice surface classifiers, Zenodo, https://doi.org/10.5281/zenodo.3564529, last access: January 2020b.

Cook, J. M., Tedstone, A. J., Williamson, C., and McCutcheon, J.: Field and associated data, Zenodo, https://doi.org/10.5281/zenodo.3564501, last access: January 2020c.

Dauchet, J., Blanco, S., Cornet, J.-F., and Fournier, R.: Calculation of radiative properties of photnthetic microorganisms, J. Quant. Spectrosc. Ra., 161, 60-84, 2015.

Dee, D. P., Uppala, S. M., Simmons, A. J., Berrisford, P., Poli, P., Kobayashi, S., Andrae, U., Balmaseda, M. A., Balsamo, G., Bauer, P., Bechtold, P., Beljaars, A. C. M., van de Berg, I., Biblot, J., Bormann, N., Delsol, C., Dragani, R., Fuentes, M., Greer, A. J., Haimberger, L., Healy, S. B., Hersbach, H., Holm, E. V., Isaksen, L., Kallberg, P., Kohler, M., Matricardi, M., McNally, A. P., Mong-Sanz, B. M., Morcette, J.-J., Park, B.-K., Peubey, C., de Rosnay, P., Tavolato, C., Thepaut, J. N., and Vitart, F.: The ERAInterim reanalysis: Configuration and performance of the data assimilation system, Q. J. Roy. Meteorol. Soc., 137, 553-597, https://doi.org/10.1002/qj.828, 2011.

Dial, R., Ganey, G., and Skiles, S. M.: What colour should glacier algae be? An ecological role for red carbon in the cryosphere, FEMS Microbiol. Ecol., 94, fiy2007, https://doi.org/10.1093/femsec/fiy007, 2018.

Egan, W. G. and Hilgeman, T. W.: Optical properties of inhomogenous materials: applications to geology, astronomy, chemistry and engineering, Academic Press, San Diego, USA, ISBN: $0122326504,1979$.

Enderlin, E. M., Howat, I. M., Jeong, S., Noh, M.-J., van Angelen, J. H., and van den Broeke, M. R.: An improved mass budget for the Greenland ice sheet, Geophys. Res. Lett., 41, 866-872, https://doi.org/10.1002/2013GL059010, 2014.

Fettweis, X., Box, J. E., Agosta, C., Amory, C., Kittel, C., Lang, C., van As, D., Machguth, H., and Gallée, H.: Reconstructions of the 1900-2015 Greenland ice sheet surface mass balance using the regional climate MAR model, The Cryosphere, 11, 1015-1033, https://doi.org/10.5194/tc-11-1015-2017, 2017.

Flanner, M. G., Zender, C. S., Randerson, J. T., and Rasch, P. J.: Present-day climate forcing and response from black carbon in snow, J. Geophys. Res., 112, D11202, https://doi.org/10.1029/2006JD008003, 2007.

Ganey, G. Q., Loso, M. G., Burgess, A. B., and Dial, R. $\mathrm{J}$.: The role of microbes in snowmelt and radiative forcing on an Alaskan icefield, Nat. Geosci., 10, 754-759, https://doi.org/10.1038/ngeo3027, 2017.

GDAL/OGR contributors: GDAL/OGR Geospatial Data Abstraction software Library, Open Source Geospatial Foundation, available at: https://gdal.org/ (last access: January 2020), 2019.

Green, R. O., Dozier, J., Roberts, D., and Painter, T. H.: Spectral snow-reflectance models for grain size and liquid water fraction in melting snow for the solar reflected spectrum, Ann. Glaciol., 34, 71-73, 2002.

Greene, C. A., Gwyther, D. E., and Blankenship, D. D.: Antarctic Mapping Tools for Matlab, Comput. Geosci., 104, 151-157, https://doi.org/10.1016/j.cageo.2016.08.003. 2017.

Haardt, H. and Maske, H.: Specific in vivo absorption coefficient of chlorophyll a at $675 \mathrm{~nm}$, Limnol. Oceanogr., 32, 608-619, 1987.

Hanna, E., Navarro, F. J., Pattyn, F., Domingues, C. M., Fettweiss, X., Ivins, E. R., Nicholls, R. J., Ritz, C., Smith, B., Tulaczyk, S., Whitehouse, P., and Zwally, J.: Ice sheet mass balance and climate change. Nature, 498, 51-59, https://doi.org/10.1038/nature12238, 2013.

Hillebrand, H., Dürselen, C.-D., Kirschtel, D., Pollingher, U., and Zohary, T.: Biovolume calculation for pelagic and benthic microalgae, J. Phycol., 35, 403-24, 1999.

Howat, I.: MEaSUREs Greenland Ice Mapping Project (GIMP) Land Ice and Ocean Classification Mask, Version 1., NASA National Snow and Ice Data Center Distributed Active Archive Center, Boulder, Colorado USA, https://doi.org/10.5067/B8X58MQBFUPA (last access: August 2018), 2017.

Howat, I. M., Negrete, A., and Smith, B. E.: The Greenland Ice Mapping Project (GIMP) land classification and surface elevation data sets, The Cryosphere, 8, 1509-1518, https://doi.org/10.5194/tc-8-1509-2014, 2014.

Hu, W.: Dry weight and cell density of individual algal and cyanobacterial cells for algae research and develop- 
ment, $\mathrm{PhD}$ thesis, University of Missouri-Columbia, available at: https://mospace.umsystem.edu/xmlui/bitstream/handle/ 10355/46477/research.pdf (last access: September 2019), 2014.

Huovinen, P., Ramirez, J., and Gomez, I.: Remote sensing of albedo-reducing snow algae and impurities in the Maritime Antarctic, ISPRS J. Photogramm., 146, 507-517, 2018.

Jäger, C., Fabian, D., Schrempel, F., Dorschner, J., Henning, T., and Wesch, W.: Structural processing of enstatite by ion bombardement, Astron. Astrophys. 401, 57-65, https://doi.org/10.1051/0004-6361:20030002, 2003.

Jonsell, U., Hock, R., and Holmgren, B.: Spatial and temporal variations in albedo on Storglaciären, Sweden, J. Glaciol., 49, 59-68, https://doi.org/10.3189/172756503781830980, 2003.

Kirk, J. T. O.: A theoretical analysis of the contribution of algal cells to the attenuation of light within natural waters III. Cylindrical and spheroidal cells, New Phytol., 77, 341-358, 1976.

Knap, W. H., Brock, B. W., Oerlemans, J., and Willis, I. C.: Comparison of Landsat TM- derived and ground-based albedos of Haut Glacier d'Arolla, Switzerland, Int. J. Remote Sens., 20, 32933310, 1999.

Langen, P. L., Fauso, R. S., Vendecrux, B., Mottram, R. H., and Box, J. E.: Liquid water flow and retention on the Greenland Ice Sheet in the regional climate model HIRHAM5: local and large scale impacts, Front. Earth Sci., 4, 110, https://doi.org/10.3389/feart.2016.00110, 2017.

Lee, E. and Pilon, L.: Absorption and scattering by long and randomly oriented linear chains of spheres, J. Opt. Soc. Am., 30, 1892-1900, 2013.

Leya, T.: Fedlstudien und genetische Untersuchungen zur Kyrophilie der Schneealgen Nordwestspitzbergens, Shaker Verlag, Aachen, 2014.

Liang, S.: Narrowband to broadband conversions of land surface albedo I. Remote Sens. Environ., 76, 213-238, https://doi.org/10.1016/S0034-4257(00)00205-4, 2001.

Lutz, S., Anesio, A. M., Jorge Villar, S. E., Benning, L. G.: Variations of algal communities cause darkening of a Greenland glacier, FEMS Microbiol. Ecol., 89, 402-414, https://doi.org/10.1111/1574-6941.12351, 2014.

Lutz, S., McCutcheon, J., McQuaid, J. B., and Benning, L. G.: The diversity of ice algal communities on the Greenland Ice Sheet revealed by oligotyping, Microb. Genom., 4, 1-10, https://doi.org/10.1099/mgen.0.000159, 2018.

Masojídek, J., Torzillo, G., and Koblížek, M.: Photosynthesis in Microalgae, in: Handbook of Microalgal Culture, edited by: Richmond, A. and Hu, Q., John Wiley and Sons, Ltd., https://doi.org/10.1002/9781118567166.ch2, 2013.

McCutcheon, J., Lutz, S., Williamson, C., Cook, J. M., Tedstone, A. J., Vanderstraeten, A., Wilson, S. A., Stockdale, A., Bonneville, S., McQuaid, J. B., Tranter, M., and Benning, L. G.: Mineral phosphorous drives glacier algal blooms on the Greenland Ice Sheet, in preparation, 2020.

Micasense: Red-Edge camera radiometric calibration model, available at: https://support.micasense.com/hc/en-us/articles/ 115000351194-RedEdge-Camera-Radiometric-Calibration-Model (last access: November 2018), 2019.

Morel, A. and Bricaud, A.: Theoretical results concerning light absorption in a discrete medium, and application to specific absorption of phytoplankton, Deep-Sea Res., 28, 1375-1393, 1981.
Muller, F. and Keeler, C. M.: Errors in short term ablation measurements on melting ice surfaces, J. Glaciol., 8, 91-105, 1969.

Ngheim, S. V., Hall, D. K., Mote, T. L., Tedesco, M. A1bert, M. R., Keegan, K., Shuman, C. A., DiGirolamo, N. E., and Neumann, G.: The extreme melt across the Greenland Ice Sheet in 2012, Geophys. Res. Lett., 39, L20502, https://doi.org/10.1029/2012GL053611, 2012.

Nitsche, R. and Fritz, T.: Precise determination of the complex optical constant of mica, Appl. Opt., 43, 3263, https://doi.org/10.1364/ao.43.003263, 2004.

Noël, B., van de Berg, W. J., Machguth, H., Lhermitte, S., Howat, I., Fettweis, X., and van den Broeke, M. R.: A daily, $1 \mathrm{~km}$ resolution data set of downscaled Greenland ice sheet surface mass balance (1958-2015), The Cryosphere, 10, 2361-2377, https://doi.org/10.5194/tc-10-2361-2016, 2016.

Nordenskiöld, A. E.: Cryoconite found 1870, 19-25 July, on theinland ice, east of Auleitsivik Fjord, Disco Bay, Greenland, Geol. Mag., 2, 157-162, 1875.

OCDB: Optical Constants Database, Laboratory Astrophysics Group of the AIU Jena, Stubachtal Olivine dataset, available at: https://www.astro.uni-jena.de/Laboratory/OCDB/data/ silicate/crystalline/oliv_vis.txt (last access: November 2019), 2002.

Osborne, M.: Ardupilot Mission Planner (v1.3.48), available at: https://ardupilot.org/ardupilot/index.html, 2017.

Painter, T. H., Duval, B., and Thomas, W. H.: Detection and quantification of snow algae with an airborne imaging spectrometer, Appl. Environ. Microbiol., 67, 5267-5272, https://doi.org/10.1128/AEM.67.11.5267-5272.2001, 2001.

Pollack, J. B., Toon, O. B., and Khare, B. K.: Optical properties of some terrestrial rocks and glasses, Icarus, 19, 372-389, 1973.

Remias, D., Schwaiger, S., Aigner, S., Leya, T., Stuppner, H., and Lutz, C.: Characterization of an UV- and VISabsorbing, purpurogallin-derived secondary pigment new to algae and highly abundant in Mesotaenium berggrenii (Zygnematophyceae, Chlorophyta), an extremophyte living on glaciers, FEMS Microbiol. Ecol., 79, 638-648, https://doi.org/10.1111/j.1574-6941.2011.01245.x, 2012.

Rothman, L. S., Rinsland, C. P., Goldman, A., Massie, S. T., Edwards, D. P., Flaud, J.-M., Perrin, A., Camy-Peyrey, C., Dana, V., Mandin, J.-Y., Schroeder, J., McCann, A., Gamache, R. R., Wattson, R. B., Yohino, K., Chance, K. V., Jucks, K. W., Brown, L. R., Nemtchinov, V., and Varanasi, P.: The HITRAN molecular spectroscopic database and HAWKS (HITRAN atmospheric workstation): 1996 edition, J. Quant. Spectrosc. Ra., 60, 665710, https://doi.org/10.1016/S0022-4073(98)00078-8, 1998.

Roush, T., Pollack, J., and Orenberg, J.: Derivation of midinfrared (5-25 $\mu \mathrm{m})$ optical constants of some silicates and palagonite, Icarus, 94, 191-208, 1991.

Ryan, J., Hubbard, A., Irvine-Fynn, T. D., Doyle, S. ., Cook, J. M., Stibal, M., and Box, J. E.: How robust are in situ observations for validating satellite-derived albedo over the dark zone of the Greenland Ice Sheet?, Geophys. Res. Lett., 44, 6218-6225, 2017.

Ryan, J., Hubbard, A., Irvine-Fynn, Cook, J. T., Smith, L. C., Cameron, K., and Box, J. E.: Dark zone of the Greenland Ice Sheet controlled by distributed biologically-active impurities, Nat. Commun., 9, 1065, https://doi.org/10.1038/s41467018-03353-2, 2018a. 
Ryan, J., van As, D., Cooley, S. W., Cooper, M. G., Pitcher, L. H., and Hubbard, A.: Greenland Ice Sheet surface melt amplified by snow line migration and bare ice exposure, Sci. Adv., 5, eeav3738, https://doi.org/10.1126/sciadv.aav3738, 2018b.

Sanna, L. and Romeo, A.: Mineralogy and geochemistry of cryoconite sediments in Eqip Sermia glacier (central-west Greenland), J. Mediterr. Earth Sci., 10, 159-166, 2018.

Seager, S., Turner, E. L., Schafer, J., and Ford, E. B.: Vegetation's red edge: a possible spectroscopic biosignature of extraterrestrial plants, Astrobiology, 5, 372-390, 2005

Shepherd, A., Ivins, E. R., Barletta, V. R., Bentley, M. J., Bettadpur, S., Briggs, K. H., Bromwich, D. H., Forsberg, R., Galin, N., Horwath, M., Jacobs, S., Joughin, I., King, M. A., Lenaerts, J. T. M., Li, J., Ligtenberg, S. R. M., Luckman, A., Luthcke, S. B., McMillan, M., Meister, R., Milne, G., Mouginot, J., Muir, A., Nicolas, J. P., Paden, J., Payne, A. J., Pritchard, H., Rignot, E., Rott, H., Sohn, H.G. Rensen, L. S., Scambos, T. A., Scheuchl, B., Schrama, E. J. O., Smith, B., Sundal, A. V., van Angelen, J. H., van de Berg, W. J., van den Broeke, M. R., Vaughan, D. G., Velicogna, I., Wahr, J., Whitehouse, P. L., Wingham, D. J., Yi, D., Young, D., and Zwally, H. J.: A Reconciled Estimate of Ice-Sheet Mass Balance, Science, 338, 1183-1189, https://doi.org/10.1126/science.1228102, 2012.

Shimada, R., Takeuchi, N., and Aoki, T.: Inter-annual and geographical variations in the extent of bare ice and dark ice on the Greenland ice sheet derived from MODIS satellite images, Front. Earth Sci., 4, 43, https://doi.org/10.3389/feart.2016.00043, 2016.

Skiles, S. M., Painter, T. H., and Okin, G. S.: A method to retrieve the spectral complex refractive index and single scattering optical properties of dust deposited in mountain snow, J. Glaciol., 63, 133-147, https://doi.org/10.1017/jog.2016.126, 2017.

Smeets, C. J. P. P. and Van den Broeke, M. R.: Temporal and spatial variations of the aerodynamic roughness length in the ablation zone of the Greenland ice sheet, Bound.-Lay. Meteorol., 128, 315-338, https://doi.org/10.1007/s10546-008-9291-0, 2008.

Stibal, M., Box, J. E., Cameron, K. A., Langen, P. L., Yallop, M., Mottram, R. H., Khan, A. L., Molotch, N. P., Chrismas, N. A. M., Quaglia, F. C., Remias, D., Smeets, C. J. P., van den Broecke, M. R., Ryan, J. C., Hubbard, A., Tranter, M., van As, D., and Ahlstrøm, A. P.: Algae drive enhanced darkening of bare ice on the Greenland Ice Sheet, Geophys. Res. Lett., 44, 11463-11471, 2017

Stroeve, J., Box, J. E., Wang, Z., Schaaf, C., and Barett, A.: Re-evaluation of MODIS MCD43 Greenland albedo accuracy and trends, Remote Sens. Environ., 138, 99-214. https://doi.org/10.1016/j.rse.2013.07.023, 2013.

Takeuchi, N., Dial, R., Kohshima, S., Segawa, T., and Uetake, J.: Spatial distribution and abundance of red snow algae on the Harding Icefield, Alaska derived from a satellite image, Geophys. Res. Lett., 33, L21502, https://doi.org/10.1029/2006GL027819, 2006.

Tedesco, M., Foreman, C., Anton, J., Steiner, N., and Schwartzman, T.: Comparative analysis of morphological, mineralogical and spectral properties of cryoconite in Jakobshavn Isbræ, Greenland, and Canada Glacier, Antarctica, Ann. Glaciol., 54, 147157, https://doi.org/10.3189/2013AoG63A417, 2013.

Tedesco, M., Doherty, S., Fettweis, X., Alexander, P., Jeyaratnam, J., and Stroeve, J.: The darkening of the Greenland ice sheet: trends, drivers, and projections (1981-2100), The Cryosphere, 10, 477-496, https://doi.org/10.5194/tc-10-477-2016, 2016.

Tedstone, A. J.: Python implementation of point surface energy balance model, Zenodo, https://doi.org/10.5281/zenodo.3228331, 2019.

Tedstone, A. J., Bamber, J. L., Cook, J. M., Williamson, C. J., Fettweis, X., Hodson, A. J., and Tranter, M.: Dark ice dynamics of the south-west Greenland Ice Sheet, The Cryosphere, 11, 24912506, https://doi.org/10.5194/tc-11-2491-2017, 2017.

Tedstone, A. J., Cook, J. M., Williamson, C. J., Hofer, S., McCutcheon, J., Irvine-Fynn, T., Gribbin, T., and Tranter, M.: Algal growth and weathering crust structure drive variability in Greenland Ice Sheet ice albedo, The Cryosphere Discuss., https://doi.org/10.5194/tc-2019-131, in review, 2019.

Toon, O. B., McKay, C. P., Ackerman, T. P., and Santhanam, K.: Rapid calculation of radiative heating rates and photodissociation rates in inhomogeneous multiple scattering atmospheres, J. Geophys. Res., 94, 16287-16301, https://doi.org/10.1029/JD094iD13p16287, 1989.

Uetake, J., Naganuma, T., Hebsgaard, M. B., Kanda, H., and Kohshima, S.: Communities of algae and cyanobacteria on glaciers in west Greenland, Polar Sci., 4, 71-80, https://doi.org/10.1016/j.polar.2010.03.002, 2010.

United States Geological Survey (USGS): Unmanned Aircraft Systems data post-processing: Structure from motion photogrammetry, available at: https://uas.usgs.gov/nupo/ pdf/PhotoScanProcessingMicaSenseMar2017.pdf (last access: May 2018), 2017.

van As, D., Van den Broeke, M. R., Reijmer, C. H., and Vande Wal, R. S. W.: The summer surface energy balance of the high Antarctic Plateau, Bound.-Lay. Meteorol., 115, 289-317, https://doi.org/10.1007/s10546-004-4631-1, 2005.

van As, D., Hubbard, A. L., Hasholt, B., Mikkelsen, A. B., van den Broeke, M. R., and Fausto, R. S.: Large surface meltwater discharge from the Kangerlussuaq sector of the Greenland ice sheet during the record-warm year 2010 explained by detailed energy balance observations, The Cryosphere, 6, 199-209, https://doi.org/10.5194/tc-6-199-2012, 2012.

van As, D., Bech Mikkelsen, A., Holtegaard Nielsen, M., Box, J. E., Claesson Liljedahl, L., Lindbäck, K., Pitcher, L., and Hasholt, B.: Hypsometric amplification and routing moderation of Greenland ice sheet meltwater release, The Cryosphere, 11, 1371-1386, https://doi.org/10.5194/tc-11-1371-2017, 2017.

van den Broeke, M. R., Enderlin, E. M., Howat, I. M., Kuipers Munneke, P., Noël, B. P. Y., van de Berg, W. J., van Meijgaard, E., and Wouters, B.: On the recent contribution of the Greenland ice sheet to sea level change, The Cryosphere, 10, 1933-1946, https://doi.org/10.5194/tc-10-1933-2016, 2016.

van Diedenhoven, B., Ackerman, A. S., Cairns, B., and Fridlind, A. M.: A flexible paramaterization for shortwave optical properties of ice crystals, J. Atmos. Sci., 71, 1763-1782, https://doi.org/10.1175/JAS-D-13-0205.1, 2014.

Wang, S., Tedesco, M., Xu, M., and Alexander, P. M.: Mapping ice algal blooms in southwest Greenland from space, Geophys. Res. Lett., 45, 11779-11788, https://doi.org/10.1029/2018GL080455, 2018.

Warren, S. G.: Optical properties of snow, Rev. Geophys., 20, 6789, https://doi.org/10.1029/RG020i001p00067, 1982. 
Warren, S. G. and Brandt, R. E.: Optical constants of ice from the ultraviolet to the microwave: A revised compilation, J. Geophys. Res., 113, D14220, https://doi.org/10.1029/2007JD009744,2008, 2008.

Wharton, R. A., McKay, C. P., Simmons, G. M., and Parker, B. C.: Cryoconite holes on glaciers, BioScience, 35, 499-503, 1985.

Wientjes, I. G. M. and Oerlemans, J.: An explanation for the dark region in the western melt zone of the Greenland ice sheet, The Cryosphere, 4, 261-268, https://doi.org/10.5194/tc-4-261-2010, 2010.

Wientjes, I. G. M., Van de Wal, R. S. W., Reichart, G. J., Sluijs, A., and Oerlemans, J.: Dust from the dark region in the western ablation zone of the Greenland ice sheet, The Cryosphere, 5, 589-601, https://doi.org/10.5194/tc-5-589-2011, 2011.
Williamson, C. J., Anesio, A. M., Cook, J., Tedstone, A., Poniecka, E., Holland, A., Fagan, D., Tranter, M., and Yallop, M. L.: Ice algal bloom development on the surface of the Greenland Ice Sheet, FEMS Microbiology Ecology, fiy025, https://doi.org/10.1093/femsec/fiy02, 2018.

Williamson, C. J., Cameron, K. A., Cook, J. M., Zarsky, J. D., Stibal, M., and Edwards, A.: Glacier Algae: A Dark Past and a Darker Future, Front. Microbiol., 10, 524, https://doi.org/10.3389/fmicb.2019.00524, 2019.

Yallop, M. L., Anesio, A. J., Perkins, R. G., Cook, J., Telling, J., Fagan, D., MacFarlane, J., Stibal, M., Barker, G., Bellas, C., Hodson, A., Tranter, M., Wadham, J., and Roberts, N. W.: Photophysiology and albedo-changing potential of the ice-algal community on the surface of the Greenland ice sheet, ISME J., 6, 2302-2313, 2012. 